\title{
Shifting Diatom-Dinoflagellate Dominance During Spring Bloom in the Baltic Sea and its Potential Effects on Biogeochemical Cycling
}

OPEN ACCESS

Edited by:

Michael Arthur St. John, Technical University of Denmark,

Denmark

Reviewed by:

Maren Voss,

Leibniz Institute for Baltic Sea

Research (LG), Germany

Bernd Wemheuer,

University of New South Wales,

Australia

*Correspondence:

Kristian Spilling

kristian.spilling@environment.fi

Specialty section:

This article was submitted to

Marine Ecosystem Ecology,

a section of the journal

Frontiers in Marine Science

Received: 30 April 2018

Accepted: 27 August 2018

Published: 19 September 2018

Citation:

Spilling K, Olli K, Lehtoranta J, Kremp A, Tedesco L, Tamelander T, Klais $R$, Peltonen $\mathrm{H}$ and Tamminen $T$ (2018) Shifting Diatom-Dinoflagellate

Dominance During Spring Bloom in the Baltic Sea and its Potential Effects on Biogeochemical Cycling.

Front. Mar. Sci. 5:327.

doi: 10.3389/fmars.2018.00327

\begin{abstract}
Kristian Spilling ${ }^{1,2 *}$, Kalle Olli, ${ }^{3,4}$, Jouni Lehtoranta ${ }^{1}$, Anke Kremp ${ }^{1}$, Letizia Tedesco ${ }^{1}$, Tobias Tamelander ${ }^{2}$, Riina Klais ${ }^{3}$, Heikki Peltonen ${ }^{1}$ and Timo Tamminen ${ }^{1}$

${ }^{1}$ Finnish Environment Institute (SYKE), Helsinki, Finland, ${ }^{2}$ Tvärminne Zoological Station, Faculty of Biological and Environmental Sciences, University of Helsinki, Hanko, Finland, ${ }^{3}$ Institute of Ecology and Earth Sciences, University of Tartu, Tartu, Estonia, ${ }^{4}$ Institute of Agricultural and Environmental Sciences, Estonian University of Life Sciences, Tartu, Estonia
\end{abstract}

The Baltic Sea is affected by a range of human induced environmental pressures such as eutrophication. Here we synthesize the ongoing shift from diatom dominance toward more dinoflagellates in parts of the Baltic Sea during the spring bloom and its potential effects on biogeochemical cycling of key elements (e.g., C, N, and P). The spring bloom is the period with the highest annual primary production and sinking of organic matter to the sediment. The fate of this organic matter is a key driver for material fluxes, affecting ecosystem functioning and eutrophication feedback loops. The dominant diatoms and dinoflagellates appear to be functionally surrogates as both groups are able to effectively exhaust the wintertime accumulation of inorganic nutrients and produce bloom level biomass that contribute to vertical export of organic matter. However, the groups have very different sedimentation patterns, and the seafloor has variable potential to mineralize the settled biomass in the different sub-basins. While diatoms sink quickly out of the euphotic zone, dinoflagellates sink as inert resting cysts, or lyse in the water column contributing to slowly settling phyto-detritus. The dominance by either phytoplankton group thus directly affects both the summertime nutrient pools of the water column and the input of organic matter to the sediment but to contrasting directions. The proliferation of dinoflagellates with high encystment efficiency could increase sediment retention and burial of organic matter, alleviating the eutrophication problem and improve the environmental status of the Baltic Sea.

\footnotetext{
Keywords: eutrophication, pelagic-benthic coupling, ecosystem functioning, community composition, plankton sedimentation, carbon sink
}

\section{INTRODUCTION}

Global change is causing drastic changes to the lowest levels of the marine food web (Halpern et al., 2008; Duarte, 2014), with evidence of shifting community composition of primary producers in e.g., the North Atlantic (Leterme et al., 2005), the North Sea (Hinder et al., 2012), parts of the Mediterranean Sea (Mercado et al., 2007) and the Baltic Sea (Klais et al., 2011). The main drivers/pressures for this change are warming of the surface water, changes in stratification, eutrophication, ocean acidification, overfishing, loss of biodiversity, spreading of non-indigenous species and increasing UV exposure (e.g., Hallegraeff, 2010; Duarte, 2014). 
Different species of phytoplankton have different traits (Litchman and Klausmeier, 2008), most notably size and shape, growth rate, life history, and behavior such as motility that together determine their ecological niche and preferred environmental conditions, and phytoplankton is a major driver for global carbon fixation and biogeochemical cycles. State-ofthe-art biogeochemical models typically have several functional groups of phytoplankton, but as the models become more advanced we need empirical studies to disentangle what effect the observed shifts in phytoplankton communities have on ecosystem functioning (Fennel and Neumann, 2014).

The Baltic Sea is among the shelf seas projected to change most rapidly, due to its close interaction with land and reduced alkalinity (Niiranen et al., 2013; BACCI, 2015). Eutrophication is one of the main threats to the Baltic Sea ecosystem (e.g., HELCOM, 2009), but also ocean acidification (Havenhand, 2012; Omstedt et al., 2014), global warming (Belkin, 2009; Meier et al., 2014) and pollutants (HELCOM, 2010) greatly affect this ecosystem and pose challenges for effective management of natural habitats (Elmgren et al., 2015).

Long-term eutrophication in the Baltic Sea has led to accumulation of phosphorus (P), particularly in the sediment, to an extent that internal loading off-sets reduction in nutrient loading from the catchment (Gustafsson et al., 2012). Spread of hypoxia in the bottom water and sediments directly affect the cycling of the main elements (Conley et al., 2011; Carstensen et al., 2014), which in turn affects the community of primary producers when bottom water is transported to the surface during seasonal turnover or upwelling (Cloern, 2001).

Global warming is projected to reduce the sea ice coverage, ice thickness and increase water temperature in the Baltic Sea (Thomas et al., 2017). Expected increase in precipitation in the Northern Baltic catchment will affect freshwater inflow and nutrient run-off (Andersson et al., 2015). Changes to both temperature and freshwater inflow have the potential to change stratification of water layers, with direct implications for vertical transport of $\mathrm{O}_{2}$ and for planktonic life forms, in particular during the build-up of stratification in spring (Stipa, 2004). Input of freshwater will also influence the concentration of dissolved organic matter with implication for light dependent phytoplankton (Andersson et al., 2018). At present, freshwater induced stratification is important for the initial start of the spring bloom, but thermal stratification may become more important in the future (Hordoir and Meier, 2012). Warming of the Baltic Sea has already caused temporal shifts in the phytoplankton distribution during the highly productive spring, with earlier and more prolonged spring bloom (Groetsch et al., 2016; Kahru et al., 2016). In addition, longterm monitoring data suggest that the phytoplankton community is changing during spring in some areas of the Baltic Sea from diatom to dinoflagellates dominance (Klais et al., 2011), as a consequence of the ongoing climate change (Klais et al., 2013).

We have some understanding of how ongoing environmental changes affect the phytoplankton community, but much less is known how phytoplankton community composition feeds back into ecosystem functioning. Using the Baltic Sea as a case study, we review the present knowledge of the ongoing diatomdinoflagellate shift, and provide a synthesis of the existing knowledge of how the phytoplankton community composition directly affects ecosystem functioning through species-specific sedimentation, life cycle changes and yields of resting stages. We argue that the diatom to dinoflagellate shift has the potential to induce substantial changes in pelagic and benthic ecosystem functioning, and we provide a conceptual model of how this change could affect biogeochemical cycling of key elements. The ratio of diatoms to dinoflagellates was recently suggested to be a new environmental indicator, with a high ratio being associated with good environmental status as diatoms have historically dominated the spring bloom (Wasmund et al., 2017). However, a clear understanding of how this shift may affect the environment is still missing, and we argue that this shift could increase burial of organic matter, which would alleviate the eutrophication problem and improve the environmental status of the Baltic Sea.

\section{IMPORTANCE OF THE SPRING BLOOM FOR BIOGEOCHEMICAL CYCLES IN THE BALTIC SEA}

Long term Chl- $a$ data from western Gulf of Finland indicates a doubling in the biomass peak during spring from early 1970 s to mid-1980s; the trend has somewhat reversed after the early 1990s (Raateoja et al., 2005), but it is clear that much of the increased algal production resulting from eutrophication takes place during spring. In the most eutrophied parts of the Baltic Sea such as the Gulf of Finland (Figure 1), 40-60\% of annual carbon fixation takes place during the spring bloom. This covers only 3-5 weeks of the year, and a large fraction of this fixed carbon sinks to the seafloor (Lignell et al., 1993; Heiskanen, 1998).

The onset of the spring bloom is related to salinity stratification and warming of the surface water (Stipa, 2004). It typically starts in the Southern Baltic Sea in February/March and moves northwards like a mosaic of patches (Kahru and Nõmmann, 1990; Kahru et al., 1990). It reaches the Gulf of Finland in April and the Bothnian Sea and Bothnian Bay in May/June, but in the Bothnian Bay the biomass amplitude is much lower than for most other parts of the Baltic Sea. Two recent papers examining time series of the spring bloom timing point toward an earlier start and a longer bloom with lower biomass amplitude (Groetsch et al., 2016; Kahru et al., 2016) in agreement with modeling scenarios (Thomas et al., 2017). This was attributed to the general warming of the climate where the periods with warm water had expanded temporally over the main Baltic basins (Kahru et al., 2016). Kahru et al. (2016) also reported that the summer community of phytoplankton is becoming more abundant than the spring community based on satellite observations of Chl $a$. However, the Chl $a$ determination from remote sensing is difficult to estimate (Darecki and Stramski, 2004), and recent direct measurements of Chl $a$, covering large parts of the Baltic Sea, demonstrate that the Chl a concentration during spring is still much higher than during summer in the main basins of the Baltic Sea (Simis et al., 2017). 


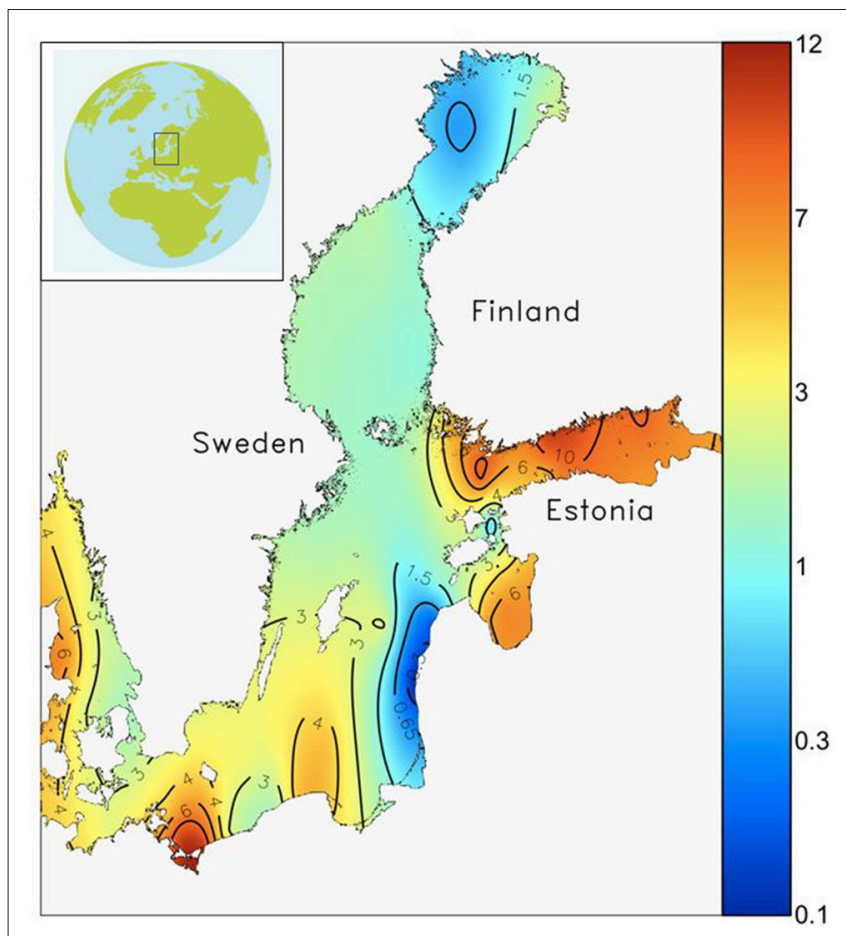

FIGURE 1 | Spatial variability of the spring bloom peak biomass (wet weight, $\left.\mathrm{mg} \mathrm{L}^{-1}\right)$ in the Baltic Sea. High biomass $\left(>6 \mathrm{mg} \mathrm{L}^{-1}\right)$ is found in the most eutrophied basins (e.g., Gulf of Finland), mid-level biomass $\left(1.5-3 \mathrm{mg} \mathrm{L}^{-1}\right.$ ) is found in the larger basins (e.g., Northern Baltic Proper, Bothnian Sea) and low biomass $\left(<1.5 \mathrm{mg} \mathrm{L}^{-1}\right)$ is found in the most oligotrophic parts (e.g., Bothnian Bay) of the Baltic Sea. The map has been modified from Klais et al. (2011).

The spring bloom in the Baltic Sea (with the exception of Bothnian Bay that is P-limited) is terminated when inorganic nitrogen has been depleted, i.e., the community is N-limited (Wulff et al., 2001; Tamminen and Andersen, 2007). The cascading effect of increased spring blooms during the last decades has led to a regime-shift-like development, i.e., nonlinear change, when inorganic $\mathrm{P}$ pools of the Baltic Proper and Gulf of Finland have remained at elevated levels ( $>0.1$ umol $\mathrm{L}^{-1}$ ) after the spring bloom (Spilling, 2007b; Raateoja et al., 2011). Low, hardly detectable phosphate concentrations were as a rule observed prior to mid-1990s, although N limitation of the spring bloom was demonstrated even then (Tamminen, 1995). Similar changes have also been reported in the Bothnian Sea (Lundberg et al., 2009; Rolff and Elfwing, 2015). The loading of $P$ from the catchment in these areas has decreased after mid1990s, seemingly a paradox, but the reason for this increase in $\mathrm{P}$ concentrations is attributed to the release of $\mathrm{P}$ from the sediment and exchange between sub-basins, which masks the realized reductions in the $\mathrm{P}$ loading (Pitkänen et al., 2001; Kiirikki et al., 2006; Stigebrandt et al., 2014; Lehtoranta et al., 2017). The sediment release of $\mathrm{P}$ might be much larger than loading from land in parts of the Baltic Sea (Conley et al., 2002), and the observed regime shift in $\mathrm{P}$ availability has seemingly affected both the magnitude and source of the P loading.

Diatoms is the only major phytoplankton group to take up substantial quantities of dissolved silicate (DSi) in addition to
$\mathrm{N}$ and P. DSi is used to build their cell walls in the form of biogenic silicate (BSi) (Martin-Jézéquel et al., 2000). The DSi originates mainly from natural processes such as weathering of rock, and human activities such as damming of rivers have reduced the natural supply DSi to the Baltic Sea (Humborg et al., 2008). In addition, eutrophication has been suggested to affect the DSi concentration; if the elevated input of $\mathrm{N}$ and $\mathrm{P}$ increases the biomass of fast growing diatoms, the flux of BSi to the seafloor could increase where it is potentially buried (Schelske and Stoermer, 1971; Conley et al., 1993). However, in the Gulf of Finland the release of DSi from the bottom and back to the water column forms a large part of the pelagic DSi pool (Tallberg et al., 2017).

The concentration of DSi is important as it may influence the competition between diatoms and others phytoplankton groups such as dinoflagellates. For example, the increased $\mathrm{N}$ :DSi ratio associated with eutrophication favors non-siliceous phytoplankton (Officer and Ryther, 1980). A molar N:DSi ratio $>2$ (Gilpin et al., 2004), or absolute concentrations of $<2 \mu \mathrm{mol}$ DSi L ${ }^{-1}$ (Egge and Aksnes, 1992) have been suggested to favor flagellates over diatoms. However, some diatoms can acclimate to DSi stress and sustain high growth rates despite low DSi concentrations (Olsen and Paasche, 1986; Brzezinski et al., 1990).

In the Baltic Sea, there has been a long term decrease in DSi concentration that has leveled off after the 2000s (Papush and Danielsson, 2006). There is a difference between the subbasins in terms of silicate budget and most of the accumulation of BSi takes place in the Gulfs of Bothnia, Finland and Riga (Papush et al., 2009), but the spring bloom diatoms are at present not DSi limited (Wasmund et al., 2013), perhaps with the exception of Gulf of Riga (Olli et al., 2008). Shifting nutrient stoichiometry could shift the competitive balance to non-siliceous phytoplankton in the future (Danielsson et al., 2008). However, many of the dominant Baltic Sea diatoms seem to be less silicified in terms of the N:Si ratio than the Redfield ratio (Spilling et al., 2010) and consequently less sensitive to low DSi concentration. An exception are their resting spores that typically have thicker frustules than the vegetative forms, and the spore formation could be affected by low DSi concentration at the end of the spring bloom (Kremp et al., 2008).

\section{Changing Phytoplankton Community}

The phytoplankton community during the highly productive spring is dominated by diatoms and dinoflagellates in most of the Baltic Sea (Niemi, 1975; Heiskanen, 1993; Wasmund et al., 1998; Höglander et al., 2004; Tamelander and Heiskanen, 2004; Jaanus et al., 2006). Diatoms are generally very successful during periods of high new production (i.e., production based on accumulated nitrate), like the spring bloom, as their higher growth rate enables them to outcompete e.g., dinoflagellates (Reynolds, 2006). This is also the case for the spring phytoplankton community in the Baltic Sea, where the dinoflagellates are not able to achieve growth rates comparable to diatoms under controlled lab conditions (Spilling and Markager, 2008). Rather, the recruitment, affecting abundances before the spring bloom start, seem to govern the success of dinoflagellates during spring bloom (Kremp et al., 2008). Additionally, certain sequences 
of weather conditions, particularly stratification periods at the onset of the spring bloom have been related to subsequent dinoflagellate dominance (Heiskanen, 1998; Höglander et al., 2004; Klais et al., 2013). Stratification beneath the ice may serve as a platform for dinoflagellates to build up high biomass already during winter (Spilling, 2007a). In addition, some dinoflagellates are mixotrophs (uptake or feeding on organic components), which may supplement $\mathrm{C}$ fixation during light limited conditions (Carlsson and Graneli, 1998; Legrand and Carlsson, 1998; Rintala et al., 2007).

In spite of varying dominance of diatoms and dinoflagellates during the spring bloom period, both of the groups are able to effectively exhaust the wintertime accumulation of inorganic $\mathrm{N}$, and produce bloom-level biomasses, and they thus appear to be functional surrogates (Kremp et al., 2008). However, the stoichiometry of the sinking material varies depending on the species composition, as diatom-dominated communities have a higher C: N: P ratio than mixed or dinoflagellate-dominated communities (Spilling et al., 2014). Changes in C: N: P ratio may have consequences for food quality and remineralization in the pelagic and benthic systems of the Baltic Sea. Grazing pressure is relatively low during the spring bloom (Lignell et al., 1993), which is the reason why much of the biomass sink to the seafloor. However, the planktonic grazer communities can be affected as changes in spring bloom composition influence the quality of food available for the emerging copepod populations (Vehmaa et al., 2011), and increasing temperature may boost heterotrophic activity and reduce the export of phytoplankton to the seafloor in the future (Tamelander et al., 2017).

The phytoplankton community composition may also affect the structure of the sinking biomass that may influence the benthic biogeochemistry. Diatoms are worldwide known to be important vehicles for transporting fixed carbon from the atmosphere to great depths (Doney, 1997; Smetacek, 1998). In the relatively shallow Baltic Sea, a large fraction of this carbon sinks to the seafloor. The majority of vegetative dinoflagellate cells lyse, in contrast to diatoms, leading to remineralization in the pelagic zone or forming of slow sinking phytodetritus (Heiskanen, 1998; Tamelander and Heiskanen, 2004). Dinoflagellates can also constitute a major fraction of the sedimentation flux, with sharp peaks during mass encystment, depending on the species and their respective encystment strategies. Built for longterm survival, the cysts that do settle, do not contribute to the benthic oxygen demand (Spilling and Lindström, 2008), although they have a similar carbon content (roughly $50 \%$ of the dry weight). Diatoms also have resting stages called spores, and there is a large variation in the amount of resting spores being produced after the bloom depending on the species, ranging from virtually none to most of the cells forming spores (e.g., Kuosa et al., 1997). The different life history traits have also been suggested to impact sedimentation of phytoplankton biomass quantitatively, with higher vertical export from diatom dominated blooms (Heiskanen, 1998). However, vertical export estimates of phytoplankton and total particulate organic carbon (POC) export vary greatly among years characterized by diatom or dinoflagellate dominance (Heiskanen, 1993, 1995; Tallberg and Heiskanen, 1998; Tamelander and Heiskanen, 2004), with no consistent trend. Conceivably, both intact cells (diatoms, spores, and cysts) and detritus (mainly from vegetative dinoflagellate cells) may settle but the share of resting stages will depend on environmental effects on cyst/spore formation and deposition, and on the life cycle strategy of the prevailing species (Kremp et al., 2009; Warns et al., 2012).

Consequently, the phytoplankton composition during the spring bloom may affect both the summertime nutrient pools of the water column, and the input of labile organic matter to the bottom sediments. In the case of diatom dominance, drawdown of nutrients to the bottom is efficient and leaves impoverished nutrient stocks for summertime regenerated production in the euphotic zone. During dinoflagellate dominance, more organic material may be available for remineralization in the productive surface layer, supporting recycling through the microbial loop. However, a complicating factor, which may counteract this assumption, is the active release of dissolved organic matter that is more prevalent during diatom dominance (CamarenaGómez et al., 2018). This can be done for several reasons (e.g., Thornton, 2014), for example stimulating bacterial growth, which may provide some benefits in return for phytoplankton like the production of B12 vitamin (Kazamia et al., 2012), or be a way to dissipate excess light energy (Zlotnik and Dubinsky, 1989).

\section{CHANGING SPECIES COMPOSITION-A FUNCTIONAL SHIFT IN THE MAKING?}

In the last few decades, the proportion of dinoflagellates in the spring bloom biomass has increased in the northern Baltic Sea, most notably in the Gulf of Finland. For example, monitoring data from the waters off the city of Helsinki (see Olli et al., 2011 for description of data), reveal that in spite of substantial variation, the proportion of dinoflagellates has increased from 10 to $20 \%$ in the 1970 s up to around $80 \%$ by the turn of the century (Figure 2). The increase of the dinoflagellate proportion has been, with varying strength, a common phenomenon in large parts of the Gulf of Finland, including the north-western part of the Gulf (e.g., archipelago off the Hanko peninsula), but also in the eastern parts of the Gulf (Klais et al., 2011). Overall, the previously diatom dominated spring blooms in the eutrophied Gulf of Finland have incrementally shifted to dinoflagellate dominated blooms in just three decades, but with large inter-annual variation. The inter-annual variation is partly climate driven (Klais et al., 2013), but the reason for the decrease of dinoflagellates in the 1990s outside Helsinki (Figure 2) is not yet resolved, suggesting other variables affecting the population dynamics e.g., the timing of recruitment is important for dinoflagellate development (Kremp et al., 2008).

In spite of the general increase in the dinoflagellate proportion in the Gulf of Finland, opposing decadal scale trends have occurred in other sub-basins. In the central Baltic Proper, where the proportion of dinoflagellates was ca. $80-90 \%$ for many decades, a slow decrease have been observed (Wasmund et al., 1998). Wasmund and Uhlig (2003) reported a weak increase of spring bloom dinoflagellate biomass in the southern Baltic Sea, but gave no data on proportions. In the eutrophied 


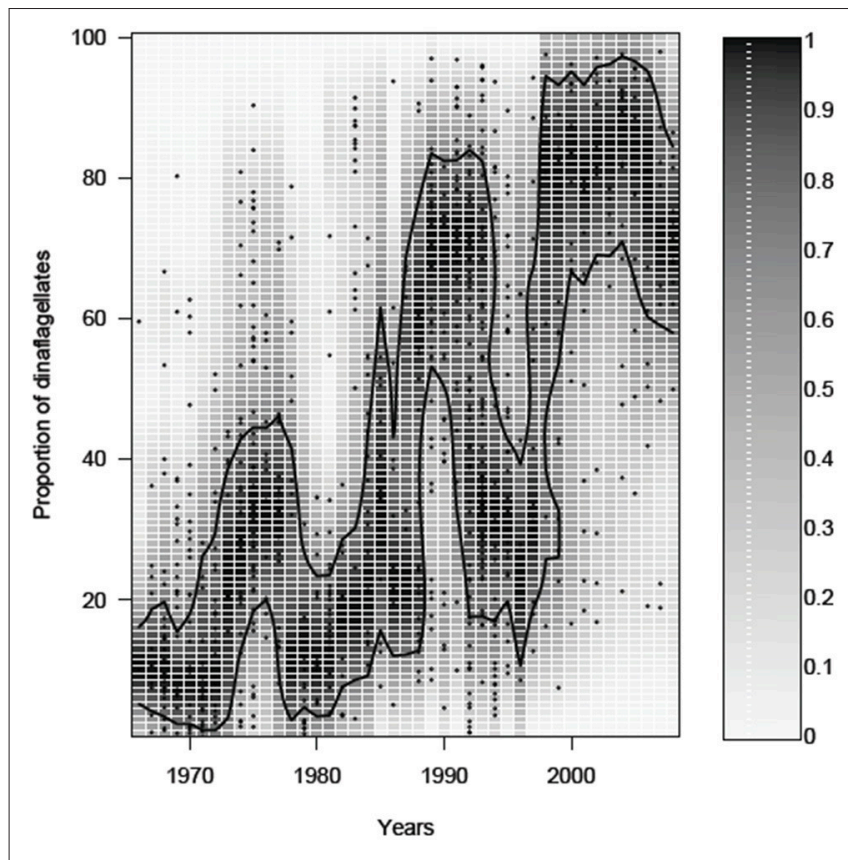

FIGURE 2 | Temporal change in the proportion of dinoflagellates from the sum of diatoms plus dinoflagellates in the spring bloom outside the city of Helsinki (Gulf of Finland). The symbols show the proportion of dinoflagellates in a particular sample. The gray scale shows the probability of having a particular dinoflagellate proportion, obtained by a kernel density estimate of a particular year. The contour line shows the $75 \%$ probability level.

Gulf of Riga, strong spring blooms of heavily silicified diatom species exhausted the dissolved silicate stocks in mid 1990s (Olli et al., 2008), giving rise to a short period of high dinoflagellate proportions, in the otherwise diatom dominated basin.

\section{Dinoflagellates}

The dinoflagellate spring bloom community includes several species that can reach high biomasses depending on conditions and location. Single-celled, medium-sized, oval-shaped dinoflagellates regularly reach high abundances in the northern basins and the central Baltic Sea. These were previously considered as one species, Scrippsiella hangoei, but high resolution scanning electron microscopy and rDNA analyses revealed that this entity is represented by at least three different species belonging to different dinoflagellate orders: Biecheleria baltica (syn Woloszynskia halophila), Apocalathium malmogiense (syn S. hangoei), and Gymnodinium corollarium (Larsen et al., 1995; Kremp et al., 2005; Moestrup et al., 2009). Records of their specific resting cysts suggest that $B$. baltica is mainly found in the northern basins, particularly the Gulf of Finland (Olli and Trunov, 2010), while G. corollarium has its main distribution in the central Baltic Sea (Sundström et al., 2009). A. malmogiense cysts are rare in Baltic surface sediments, suggesting that this species is of a minor importance in the spring dinoflagellate community (Kremp et al., 2018). In addition to the three single-celled species, the chain forming, arctic Peridiniella catenata can reach high abundances in some years during spring and it has a wide distribution in the Baltic Sea. If $B$. baltica prevails in the Gulf of Finland, the shift to dinoflagellate dominated spring blooms can be ascribed to the proliferation of this species alone (Figure 3). To the best our knowledge, $B$. baltica has not been found in any other water body and its origin remains thus enigmatic, but it seems to have a center of expansion in the western Gulf of Finland, from where it has in recent decades spread east- and westwards. Due to the potential of $B$. baltica to completely take over the spring bloom in just a few decades, its unique life history traits, recruitment preferences, and biogeochemical consequences of dominance are of great interest (see below). Despite the conspicuous expansion of $B$. baltica in the northern Baltic Sea, the species is virtually absent in the neighboring Gulf of Riga (Olli and Heiskanen, 1999), suggesting that local hydrography can act as an efficient dispersal barrier.

The major spring bloom dinoflagellates differ from each other in several functional traits, which may affect biogeochemical pathways, e.g., different life cycle strategies may affect sedimentation rate of the population. Formation and subsequent sedimentation of cysts now known to be produced by $B$. baltica at the end of the spring bloom can contribute up to $45 \%$ of the total vertical POC flux (Heiskanen, 1993) Notable cyst fluxes have also been documented for G. corollarium from the Bornholm and Gotland basins (Sundström et al., 2009). For $P$. catenata, it has been established that most of the biomass produced by this species during spring disintegrates in the water column at the end of the bloom (Heiskanen and Kononen, 1994), and only a minor part of the population undergoes encystment (Kremp, 2000; Spilling et al., 2006; Olli and Trunov, 2010).

Species-specific life cycle strategies, involving fundamentally different mechanisms leading to the respective transitions, likely affect biogeochemical processes. High cyst yields are triggered by different environmental factors and physiological processes (Kremp et al., 2009). Depending on the dominant species, specific temperature and inorganic nutrient dynamics during spring will induce different life cycle responses, with different outcomes regarding vertical fluxes of cyst bound carbon. This has been demonstrated by simulations of numerical models that explicitly consider the regulation of life cycle transitions (Warns et al., 2013). Species-specific differences also exist in germination efficiencies of cysts, which may affect the fate of cyst-bound carbon in the sediment. Of the B. baltica cysts produced, only $10-20 \%$ will germinate under optimal conditions the following spring (Kremp, 2000), which implies that B. baltica blooms could support long-term organic carbon storage in the sediments.

The behavioral adaptations of the vernal bloom influence the biogeochemical cycling within the water column. At the late phase of the spring bloom, the vertically migrating dinoflagellate cells (Olli et al., 1998) descend below the euphotic layer (30$40 \mathrm{~m}$ depth), where cyst formation takes place (Spilling et al., 2006). If only a few percent of the cells encyst at most, the bulk of the biomass disintegrates and contributes to the DOM and slowly sinking phytodetrital pools in mid-depths of the water column. This resource, re-mineralized nutrients and organic 


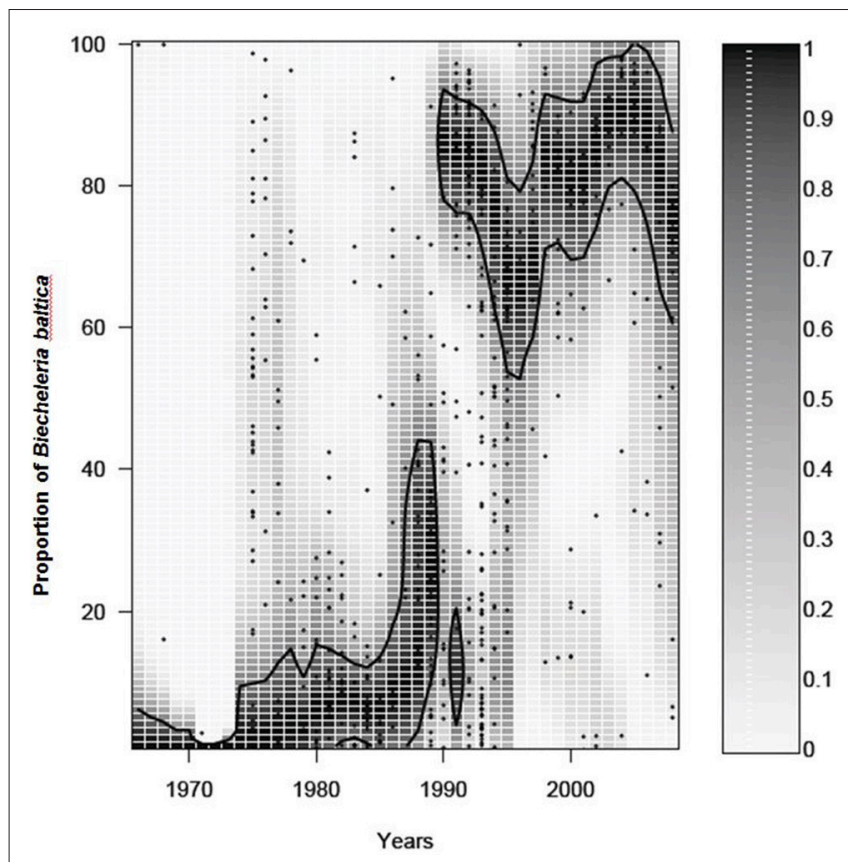

FIGURE 3 | Temporal change in the proportion of Biecheleria baltica from the total dinoflagellate biomass. All other notions as in Figure 2.

carbon substrate, will only have restricted availability to the organisms in the euphotic layer, as the rapidly establishing thermocline effectively segregates the water column. The single cell dinoflagellates, i.e., Biecheleria complex, was not found to migrate vertically in the coastal Gulf of Finland (Olli et al., 1998), but was shown to do so in the open waters of the north-western Baltic Proper, as a result of mineral nutrient depletion of the surface layer (Höglander et al., 2004). Thus the behavioral adaptations are not only species-specific, but probably also reflect regional variations in hydrodynamics and nutrient availability.

\section{Diatoms}

The diatom community tends to be more diverse during bloom conditions, compared to dinoflagellates, and functions more as a guild of complementing species (Smayda and Reynolds, 2003). This is also the case in the Baltic Sea where there are more diatom species present than dinoflagellates, but only a few species occur throughout the Baltic Sea during spring, making up a large fraction of the diatom biomass. Some of these diatoms are also present during winter in connection to the ice (Ikävalko and Thomsen, 1997), and can also be found in the Arctic, e.g., Achnanthes taeniata and Melosira arctica. These two and Thalassiosira levanderi are generally abundant in the initial phase of the spring bloom. Other abundant diatoms during the main bloom phase are Chaetoceros wighamii, C. holsaticus, Diatoma tenuis, T. baltica, and Skeletonema marinoi, where the latter typically become relatively more dominating after the peak of the spring bloom in the Gulf of Finland (Spilling, 2007b). Although some of these species occur also outside the Baltic Sea, the strong salinity gradient seems to be an effective barrier for gene exchange (Sjöqvist et al., 2015).

Diatom spores are less studied than dinoflagellate cysts in the Baltic Sea, but they seem to share many of the same characteristics. The fraction of the population that goes through the life-cycle change to form spores is highly species-specific and affected by environmental conditions (Heiskanen and Kononen, 1994; Kuosa et al., 1997). For example, A. taeniata, C. holsaticus, and $M$. arctica may settle to the seafloor primarily as spores, but the spore formation is affected e.g., by the availability of DSi, and the spore formation could be lower under less favorable conditions (Kuosa et al., 1997; Heiskanen, 1998). The functional role of diatom spores is similar to dinoflagellate cysts, i.e., long term survival in the sediment, and would thus have very much the same traits in terms of how they affect biogeochemical cycles. They can be buried and can be a useful tool for studies of paleoenvironmental changes (Witak et al., 2011). Interestingly, some spores (and also dinoflagellate cysts) are able to survive for up to a century in the sediment, enabling genetic comparison with present day strains (Härnström et al., 2011; Kremp et al., 2018). To our knowledge, there are no good estimates of how much carbon and nutrients are buried in the sediments in the form of diatom spores annually, but it is clear that the community composition is one of the key components determining this.

\section{LINKING SEDIMENTATION OF PHYTOPLANKTON TO MICROBIAL MINERALIZATION PROCESSES}

The main driver of sediment nutrient cycling is organic matter serving the energy source for heterotrophic microorganisms (Berner, 1974; Froelich et al., 1979). In addition to the organic matter, the availability of electron acceptors $\left(\mathrm{O}_{2}, \mathrm{NO}_{3}, \mathrm{Mn}\right.$, and Fe oxides and $\mathrm{SO}_{4}$ ) create the premises for the pathways of organic carbon mineralization. In the Baltic Sea, availability of organic matter and electron acceptors vary in the bottoms of the different sub-basins. For example, the sediments of the Gulf of Bothnia are organic poor compared to the Gulf of Riga, the Baltic Proper and the Gulf of Finland (Lehtoranta et al., 2008; Aigars et al., 2015; Egger et al., 2015). The Bothnian Bay is oxic down to the seafloor and $\mathrm{O}_{2}$ may penetrate centimeters into the sediment (Slomp et al., 2013). The sediment of the Gulf of Riga is oxic as well, but the penetration depth varies considerably throughout the year (Aigars et al., 2015). In the oxic areas, the bottoms can use the entire set of electron acceptors to mineralize settled phytoplankton.

In contrast to the Gulf of Bothnia, the basins of the Baltic Proper suffer from long-term hypoxia and anoxia, and the $\mathrm{O}_{2}$ penetrates into the sediment only in the shallow slopes with oxic water and after major Baltic inflow events (Almroth-Rosell et al., 2015; Mohrholz et al., 2015). Further north, at the entrance of the Gulf of Finland, anoxic periods vary inter-annually and seasonally, being most common in summer (Lehtoranta et al., 2017). The pore-water concentrations of dissolved Fe are low in the sediments of this region (Lehtoranta and Heiskanen, 2003; Jilbert et al., 2011), but, the concentration of sulfate is twice as 
high as in the Bothnian Bay. So in the Baltic Proper and the Gulf of Finland microbes have reduced access to $\mathrm{O}_{2}, \mathrm{NO}_{3}$, and $\mathrm{Fe}(\mathrm{III})$, but a continuous contact to abundant sulfate.

To summarize, the ability of the benthic systems to mineralize the settled phytoplankton, their cysts, spores, and detritus is subbasin specific in the Baltic Sea. The marked changes in the pelagic ecosystem or in the hydrodynamics have the potential to induce sub-basin specific shifts in the mineralization pathways which regulate the cycles of $\mathrm{C}, \mathrm{N}, \mathrm{P}, \mathrm{Fe}, \mathrm{Mn}$, and $\mathrm{S}$ in the sediments.

\section{Settling Spring Bloom Biomass and Mineralization of $\mathbf{N}$ and $\mathbf{P}$}

Nitrate $\left(\mathrm{NO}_{3}\right)$ can be used as a nutrient in the pelagic zone and as an oxidant in mineralization and in oxidation of reduced substances such as $\mathrm{Fe}^{2+}, \mathrm{HS}^{-}, \mathrm{H}_{2} \mathrm{~S}$, and $\mathrm{CH}_{4}$ leading to formation of $\mathrm{N}_{2}$ gas in sediments. In the oxic sediments of the Baltic Sea, the coupled nitrification-denitrification takes place right below the interface between oxic and anoxic layers, and is considered to be the major pathway for denitrification in the Baltic Sea (Hietanen and Kuparinen, 2008). The organic N is mineralized first to ammonium $\left(\mathrm{NH}_{4}\right)$ and then oxidized in the presence of $\mathrm{O}_{2}$ to nitrite $\left(\mathrm{NO}_{2}\right)$ and subsequently to $\mathrm{NO}_{3}$ which feeds the denitrification process. This process forms a link between settled organic matter, nitrogen, and respiration because organic $\mathrm{C}$ is oxidized by $\mathrm{NO}_{3}$ to $\mathrm{CO}_{2}$ and nitrate is denitrified to $\mathrm{N}_{2}$ gas.

Denitrification is often seen as a negative feedback mechanism for eutrophication processes as it removes $\mathrm{N}$ from the system. Oxic conditions are needed to maintain the stock of $\mathrm{NO}_{3}$ for the coupled nitrification-denitrification, but anoxic condition is obligatory for denitrification. Vahtera et al. (2007a) suggested that the increase in size of hypoxic area in the Baltic Sea is linked to the decrease in storage of $\mathrm{N}$ through removal of $\mathrm{N}$ by denitrification. However, stratification and excess organic matter may deplete $\mathrm{O}_{2}$, which inhibits the formation of $\mathrm{NO}_{3}$ and may lead to accumulation of $\mathrm{NH}_{4}$ and decrease the $\mathrm{N}$ removal through denitrification in sediments (Jäntti and Hietanen, 2012). There is an alternative pathway for $\mathrm{N}$ removal through ammonium oxidation coupled to nitrite reduction, also leading to the production of gaseous forms of $\mathrm{N}$ (mainly $\mathrm{N}_{2}$ but also $\mathrm{NO}$ and $\mathrm{N}_{2} \mathrm{O}$ ) (Kuypers et al., 2003). This $\mathrm{N}$ removing mechanism, anammox, requires one oxidized $\mathrm{N}$ species $\left(\mathrm{NO}_{2}^{-}\right)$for every $\mathrm{N}_{2}$ molecule made, which is half the requirement of denitrification. Anammox bacteria grow relatively slowly and the lack of $\mathrm{NO}_{2}^{-}$ will also stop the anammox process. However, $\mathrm{N}$ removal might in this case take place further up in the water column in the Baltic Proper (Dalsgaard et al., 2013), but this is a process that is not very pronounced in other sub basins such as the Gulf of Finland (Jäntti and Hietanen, 2012).

The cycling of sediment $\mathrm{P}$ is intimately linked to the mineralization of the settling phytoplankton and detritus. Phosphate itself is not a redox-sensitive substance, but there is commonly a strong, negative correlation between $\mathrm{O}_{2}$ and phosphate concentrations. This relationship can largely be explained with the coupling of P to the Fe cycling (Einsele, 1938). Based on literature and the tests with estuarine sediments from the Gulf of Finland, it is evident that the mineralization through $\mathrm{Fe}(\mathrm{III})$ oxides and $\mathrm{Fe}$ reduction by $\mathrm{H}_{2} \mathrm{~S}$ (or $\mathrm{HS}^{-}$) may result in markedly different outcomes regarding cycling of $\mathrm{P}$ in different sub-basins (Lehtoranta et al., 2009).

In the Bothnian Bay, the concentrations of dissolved $\mathrm{Fe}^{2+}$ and $\mathrm{P}$ in pore water indicate that the microbial $\mathrm{Fe}$ reduction may maintain the coupled cycling of $\mathrm{Fe}$ and $\mathrm{P}$ in the sediments (Blomqvist et al., 2004; Slomp et al., 2013). The Bothnian Bay, therefore, has a great potential to capture the $\mathrm{P}$ mineralized from settled phytoplankton and detritus to newly forming $\mathrm{Fe}$ (III) oxides in the oxic zone of the sediment. Also the burial of the reduced $\mathrm{Fe}$ phosphate mineral vivianite $\left(\mathrm{Fe}_{3}\left(\mathrm{PO}_{4}\right)_{2} 8 \mathrm{H}_{2} \mathrm{O}\right)$, may enhance the $\mathrm{P}$ binding in the methanogenic zone of the Gulf of Bothnia (Slomp et al., 2013; Egger et al., 2015). In contrast to the Bothnian Bay, the formation of solid Fe sulfide minerals may block the cycling of Fe in the Baltic Proper and the Gulf of Finland (Lehtoranta et al., 2008). In these areas the dominance of sulfate reduction creates sulfidic conditions and the P mineralized from phytoplankton and Fe(III) oxides may freely escape from the sediment to water without sequestration by Fe. From a water quality perspective, the formation of Fe sulfides rapidly deteriorates environmental conditions as the ability of the sediment to sorb P into Fe is largely lost. This is the situation in the Baltic Proper and the Gulf of Finland where the sediments ability to capture $\mathrm{P}$ originating from settling algae has been reduced or lost.

It is evident that the amount of settled phytoplankton and detritus has direct consequences for the cycling of $\mathrm{N}$ and $\mathrm{P}$ in the Baltic Sea ecosystem. What is less apparent is the qualitative aspect of the settling biomass and what electron acceptor may be used in the mineralization process. Spilling and Lindström (2008) added different cultures of spring bloom algae to a natural sediment, and found that they produced very different responses in the sediment, depending on species-specific life cycle change. In short, a dinoflagellate that produced cysts did not contribute to oxygen depletion, $\mathrm{NH}_{4}$ formation and $\mathrm{P}$ release. The vegetative stages, in contrast, (of both a diatom and another dinoflagellate) quickly turned the sediment anoxic with the formation of Fe sulfides, $\mathrm{NH}_{4}$ and release of $\mathrm{P}$. This highlights the qualitative aspect of the settling material, i.e., not all of the phytoplankton settled is easily mineralized, and this is to our knowledge not taken into account in any models of biogeochemical cycling.

Resting stages, being cysts or spores, are built to survive for a long time in the sediment. The qualitative aspect of the settling biomass cannot be divided into dinoflagellates or diatoms as such, but is linked to life cycle changes. However, the amount of resting stages made after the spring bloom is species-specific, and dinoflagellates tend to produce more carbon bound to resting stages than diatoms. In particular B. baltica and G. corollarium go through mass encystment and because their germination success is low the following year, they are effective vehicles for carbon burial in the sediment. At least $B$. baltica has increased its biomass substantially over the past decades, and if this continues a larger share of the biomass produced during spring could be buried permanently at the seafloor. 


\section{Sediment Thresholds Controlling Nutrient Dynamics}

With increasing transport of phytoplankton to the seafloor, there will generally be successive, non-linear thresholds that change the mineralization pathways and geochemical conditions in the sediment. The first threshold takes place when stratification decreases the transport rate of $\mathrm{O}_{2}$ downwards, or there is an excess of organic $\mathrm{C}$ input enhancing the oxygen consumption. Both cases lead to anoxia first in the sediment and then in overlying water. Under these conditions, the coupled nitrification-denitrification is blocked and the $\mathrm{NO}_{3}$ flux from water to sediment starts to control the denitrification, which is the case in the Gulf of Riga (Aigars et al., 2015). Without oxidation of $\mathrm{NH}_{4}$ only few micromoles of labile carbon served by phytoplankton is required to deplete $\mathrm{NO}_{3}$ as the near-bottom water concentration of $\mathrm{NO}_{3}$ varies commonly from 2 to $10 \mu \mathrm{mol}$ $\mathrm{L}^{-1}$ in the Gulf of Finland. Eventually the anoxic conditions result in the accumulation of $\mathrm{NH}_{4}$ in the near-bottom water. Then the oxidation of released $\mathrm{NH}_{4}$ to $\mathrm{NO}_{3}$ may occur only in the chemocline between oxic and anoxic water layers and the formed $\mathrm{NO}_{3}$ may be denitrified with organic matter and sulfides present in anoxic water as in the Gotland Basin (Dalsgaard et al., 2013). We have modified the conceptual model of Vahtera et al. (2007a) to include the threshold regarding the cycling of N (Figure 4). Although part of the $\mathrm{N}$ removal may occur above the seafloor (Dalsgaard et al., 2013), the potential termination of N-removal could form a positive feedback loop for eutrophication.

After depletion of $\mathrm{NO}_{3}$ and in the presence of labile organic $\mathrm{C}$ in the sediment, the system is pushed toward a second threshold when microbe-driven Fe(III) reduction results in and simultaneous release of $\mathrm{Fe}$ and $\mathrm{P}$ to the near-bottom water. When Fe is diffused or transported during vertical mixing or upwelling events to an oxic environment, the newly formed $\mathrm{Fe}$ (III) oxides have the capacity to resorb $\mathrm{P}$ originating from the settled phytoplankton.

The concentration of poorly crystalline Fe(III) is suggested to control the Fe reduction rate. Four moles of $\mathrm{Fe}$ is needed to oxidize one mole of organic carbon and without re-oxidation by oxygen, $\mathrm{NO}_{3}$, and $\mathrm{Mn}$ oxides, the pool of bioavailable $\mathrm{Fe}(\mathrm{III})$ oxides can be consumed within days in organic rich marine sediments, but large regional differences are evident (Rysgaard et al., 2001; Canfield et al., 2005). The depletion of bioavailable $\mathrm{Fe}$ (III) oxides leads to a third threshold, where sulfate reduction is the dominant mineralization pathway for settled phytoplankton biomass. The passing of the third threshold forms enough sulfides capable to precipitate with reactive $\mathrm{Fe}$ and block its cycling. Under the sulfidic conditions, the sediment and water column has poor ability to bind $\mathrm{P}$ to $\mathrm{Fe}$, which results in a large release of Fe bound $\mathrm{P}$ and organic $\mathrm{P}$ and a minor release of Fe to the overlaying water. Thus, in the Baltic Sea the large pulse of $\mathrm{P}$ in the sulfidic conditions is explained by the dissolution of $\mathrm{Fe}$ (III) oxide bound $\mathrm{P}$ and the mineralization of fresh organic $\mathrm{P}$ that may be released within a short period of time compared to "old" organic $\mathrm{P}$, which may take years to remineralization in sediments (Ahlgren et al., 2006). Additionally, the high amount of labile C and abundance of $\mathrm{SO}_{4}$ maintains sulfate reduction and leads to accumulation of free sulfides in the water column as found in the bottom water of the Baltic Proper and occasionally in the Gulf of Finland. The oxidation of these sulfides in the chemocline consumes $\mathrm{O}_{2}, \mathrm{NO}_{3}, \mathrm{Mn}(\mathrm{IV})$, and $\mathrm{Fe}(\mathrm{III})$ present in the water column, delaying the recovery of the sedimentary system of the Baltic Sea. Typically, there is too little Fe to bind $\mathrm{P}$ in the water and the ability of the sediment to resorb $\mathrm{P}$ to $\mathrm{Fe}$ (III) oxides depends on the re-oxidation of the reduced Fe(II). The oxidation of $\mathrm{Fe}$ by $\mathrm{O}_{2}$ in the water takes place at a very thin surface layer, but may be extended with the help of benthic animals that burrows into the sediment, such as Marenzelleria spp., an alien species that has spread to large bottom areas in the Baltic (Norkko et al., 2012; Maximov et al., 2015).

Modeling of biogeochemical fluxes relies on the information of sediment processes and our understanding of these sediment thresholds as eutrophication increases the amount of sinking phytoplankton. We have concentrated on solving how easily degraded organic matter consume the various electron acceptors in the sediment, and how this affects material fluxes through the sediment-water interface. However, the qualitative aspect of the settling material as described above should be taken into consideration (Stolpovsky et al., 2015), in particular under the scenario with changing composition of the sinking organic matter. Another important biological process to consider is bioturbation by benthic animals, which will affect sediment processes e.g., by increasing oxygen penetration depth into the sediment (Norkko et al., 2012). Understanding the complex interplay between settling phytoplankton biomass, its quality (labile, semi-labile, or refractory) and biological activity in the sediment is the target of ongoing modeling efforts (e.g., Stolpovsky et al., 2018). In the Baltic Sea, an important step would be to better predict the quantity of the settling organic matter that will trigger the three sediment thresholds described above, taking the qualitative aspect of the biomass and bioturbation into consideration.

\section{PELAGIC NUTRIENT DYNAMICS-FROM SPRING TO SUMMER}

One of the highly visible effects of the eutrophication problem in the Baltic Sea is the increased biomass of diazotrophic cyanobacteria during summer (Elmgren et al., 2015). The prevailing $\mathrm{N}$ limitation at the end of the spring bloom leads to a low $\mathrm{N}: \mathrm{P}$ ratio during summer, which favors $\mathrm{N}$-fixing cyanobacteria during warm, calm summer months (Niemi, 1979; Wasmund et al., 2005). The cyanobacterial blooms directly affect the eutrophication problem, as their fixation of $\mathrm{N}$ is comparable in magnitude with anthropogenic loading of $\mathrm{N}$ in parts of the Baltic Sea (Savchuk, 2005; Wasmund et al., 2005). In addition to the cyanobacterial biomass, the part of the newly fixed $\mathrm{N}$ is released and may be taken up by other components in the plankton food web (Adam et al., 2016), and this may start right after the spring bloom when the water is still relatively cold $\left(10^{\circ} \mathrm{C}\right)$ (Svedén et al., 2015). The cyanobacterial input of $\mathrm{N}$ might have a self-enforcing nature by increasing the biomass load reaching the sediment, aggravating oxygen consumption and increasing release of $\mathrm{P}$ (Tamminen and Andersen, 2007; Vahtera et al., 2007a). However, we argue that the species composition 


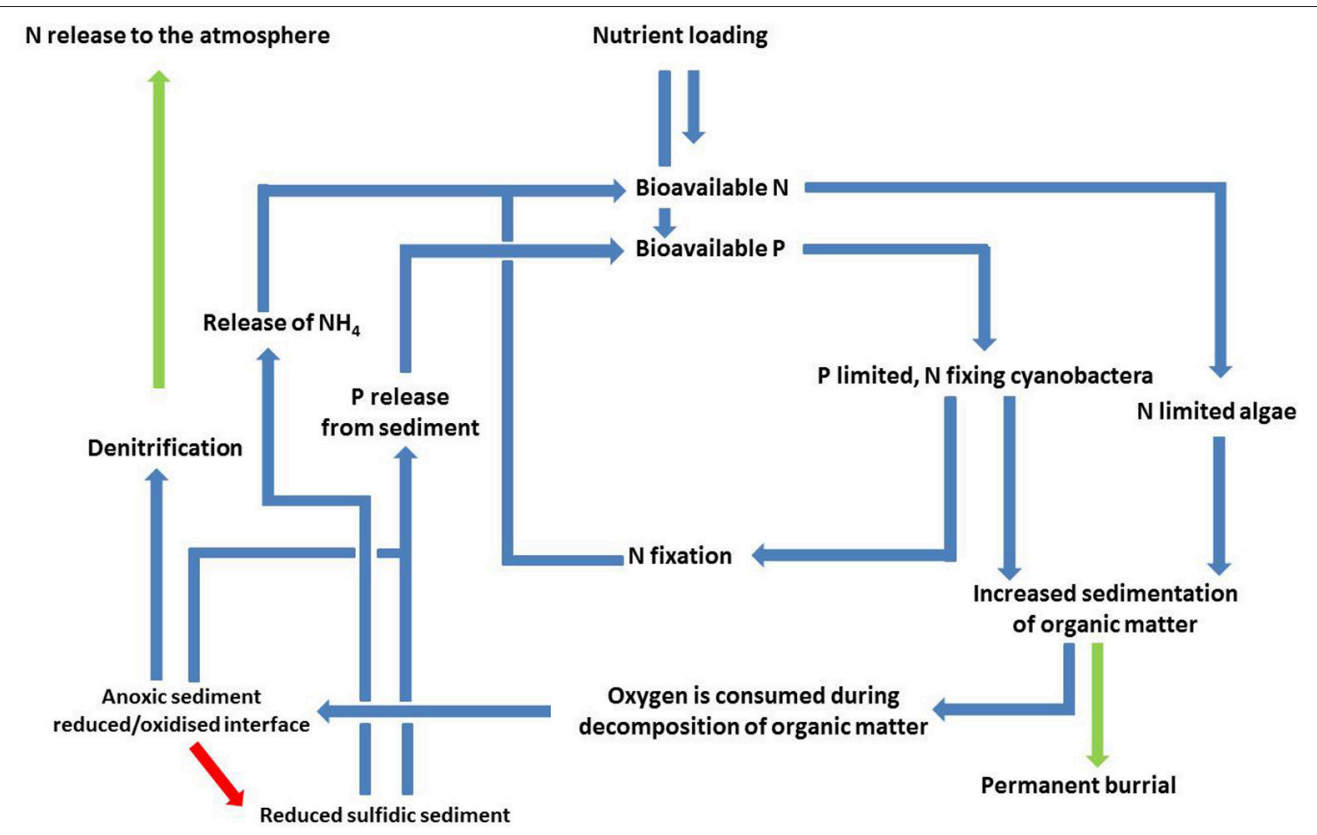

FIGURE 4 | A modified version of the vicious cycle presented in Tamminen and Andersen (2007) and Vahtera et al. (2007a) where the possible termination of denitrification has been added (red arrow). This takes place when the amount of organic matter is large enough to reduce both the sediment and bottom water, leading to a stop in the oxidation of ammonium (nitrification), which is a prerequisite for denitrificaiton to take place; however, denitrification higher in the water column may to some extent compensate for this (Dalsgaard et al., 2013). Both the quantity and quality (e.g., plankton community composition) of the spring bloom biomass may affect the magnitude of the nutrient sinks (green arrows).

of the spring bloom could affect this: with the shift toward a more dinoflagellate-dominated community (Wasmund and Uhlig, 2003; Klais et al., 2011), the sharp flux of diatom biomass to the sediment would diminish. This could have ecosystem-wide consequences as the organic material transport to the sediment affects both nitrogen and phosphorus cycles (Vahtera et al., 2007a). To some extent, the sedimentation pattern could be prolonged with more recycling in the euphotic zone (Tamelander et al., 2017), but at present we miss an understanding of how the observed shift in the spring phytoplankton community has on sedimentation and material fluxes on a large scale.

The pool of bioavailable $\mathrm{P}$ at the onset of summer is critical for the development of the cyanobacterial blooms later in the season. This has increased over large areas since the mid-1990s. In the Gulf of Finland and Baltic Proper the concentration may be as high as $>0.5 \mu \mathrm{mol} \mathrm{PO}_{4} \mathrm{~L}^{-1}$ after $\mathrm{N}$ sources have been depleted (Figure 5). In the Bothnian Sea the development is the same but with lower remaining P pool and Bothnian Bay is P limited and has an $\mathrm{N}$ surplus.

The two main cyanobacterial species: Aphanizomenon flosaquae and Nodularia spumigena have different $\mathrm{P}$ uptake strategies. A. flos-aquae requires inorganic phosphate and can take up and store excess $\mathrm{P}$ for later growth (Larsson et al., 2001; Kangro et al., 2007), whereas N. spumigena has higher affinity for P uptake and relies more on recycled P (Hagström et al., 2001; Vahtera et al., 2007b). Under stable conditions there is also a spatial separation between the main summer cyanobacteria where A. flos-aquae typically remains lower in the water column whereas $N$. spumigena is found at the surface (Hajdu et al., 2007). A. flos-aquae is the main diazotroph in the Northern Baltic Proper, and in addition to N. spumigena, also Dolichospermum spp. contributes to the $\mathrm{N}$-fixation (Klawonn et al., 2016). It is clear that cyanobacteria is benefitting from the oversupply of P (Raateoja et al., 2011), but several open questions remain. The dominant cyanobacterial species grow relatively slowly, in particular in water temperatures below $15^{\circ} \mathrm{C}$ (but $A$. flos-aquae is less temperature sensitive than $N$. spumigena), and there is typically a relatively short time window between the draw-down of bioavailable $\mathrm{P}$ and cyanobacteria growth, and it is not enough to satisfy the cyanobacterial need (Walve and Larsson, 2007; Nausch et al., 2008), so there must be other components in the plankton community that takes up the excess $\mathrm{P}$. These could be other primary producers or heterotrophic bacteria (Nausch and Nausch, 2004). The prevailing N-limitation, limits growth of other phytoplankton and consequently inhibits their uptake of excess P. Heterotrophic bacteria is probably not limited by $\mathrm{N}$, but might be limited by carbon (Lignell et al., 1992), at least their P uptake intensifies when they have a sufficient carbon source (Tamminen, 1989). To our knowledge, it is not clear what plankton groups takes up the excess $\mathrm{P}$, but it does seem to accumulate in the particulate fraction and settle before the onset of dense cyanobacterial blooms (Nausch et al., 2008). It is evident that other P sources must exist for the cyanobacterial blooms (Raateoja et al., 2011), most likely through upwelling (Wasmund et al., 2012). 

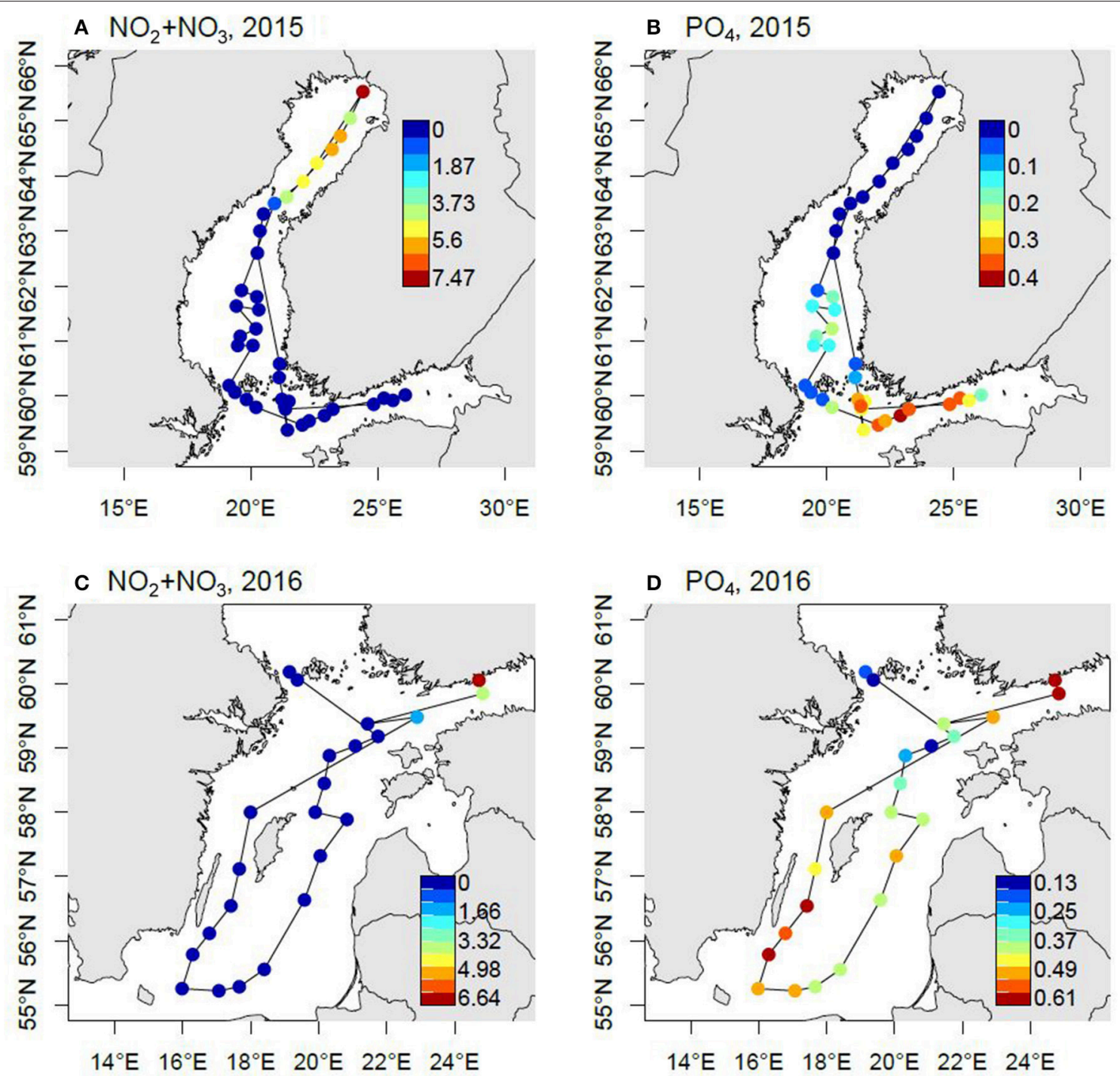

FIGURE 5 | Nutrient concentrations $\left(\mu \mathrm{mol} \mathrm{L}^{-1}\right)$ at the surface (3 m depth) following the spring bloom. The samples were taken in May 2015 (A,B) and April 2016 (C,D) during the CFLUX15 and CFLUX16 research cruise, respectively, on board R/N Aranda. The maps have been modified from Spilling (2015) and Spilling (2016).

\section{Role of Dissolved Organic Matter in Pelagic Nutrient Cycling}

Due to the close connection with land with substantial freshwater input, the Baltic Sea has a large pool of dissolved organic matter (DOM) originating from outside the system, i.e., allochthonous DOM. In addition, there are several pathways from primary production into the DOM pool, such as direct release of exudates, lysis of cells, and sloppy feeding by grazers, i.e., autochthonous DOM. DOM is a potential source of carbon (DOC), nitrogen (DON) and phosphorus (DOP) for bacterial production, which may lead to remineralization of $\mathrm{N}$ and $\mathrm{P}$ back to inorganic forms available for phytoplankton. It may also provide organic matter to higher trophic levels through the microbial loop, although this is quite inefficient in trophic transfer (Anderson and Ducklow, 2001). Part of the allochthonous DOM, approximately $10 \%$ of DOC (Asmala et al., 2013), and $~ 30 \%$ of DON and $75 \%$ of DOP
(Stepanauskas et al., 2002) is taken up by bacteria. Photochemical degradation of allochthonous DOM can also support plankton production (Vähätalo et al., 2011), and in total, approximately $50 \%$ of the riverine DOM is removed (Seidel et al., 2017). The source of DOM can also be important as it may affect the phytoplankton community composition by favoring certain species (Jurgensone and Aigars, 2012). In the future, a warmer climate might lead to more precipitation and increased input of allochthonous DOM, in particular in the Northern Baltic Sea (Andersson et al., 2015), which might reduce light-dependent primary production and increase the importance of pelagic, heterotrophic bacteria (Wikner and Andersson, 2012; Andersson et al., 2018).

The input of autochthonous DOC from primary producers ranges from 2 to $50 \%$ of the fixed carbon in estuaries, averaging around 12\% (Baines and Pace, 1991). In the Baltic Sea, there 
is an increase of DOM during the productive season (Hoikkala et al., 2012), calculated to be $20-200 \mu \mathrm{mol} \mathrm{DOC} \mathrm{\textrm {L } ^ { - 1 }}$ (Hoikkala et al., 2015). Only a part of the DOC from lysing cells is easily available for bacterial degradation, and in their review of different aquatic habitats, Søndergaard and Middelboe (1995) reported an average of $19 \%$ of the total dissolved organic carbon (DOC) pool to be labile in marine waters. However, higher percentages of 25$55 \%$ have been found in the Baltic Sea (Hoikkala et al., 2016), and Hoikkala et al. (2015) presented a conceptual model, where $\sim 50 \%$ of DOC produced by phytoplankton is rapidly degraded by bacteria. As the spring bloom depletes inorganic $\mathrm{N}$ sources in most of the sub basins of the Baltic Sea, autochthonous DON is an important component for primary and bacterial production (Korth et al., 2012). Later in the productive season $\mathrm{N}$-fixing cyanobacteria is generally P limited, and DOP is potentially important. However, Nausch et al. (2008) studied the P pools in Baltic Proper and found a stable DOP pool suggesting that production and consumption was equal, and DOP was not a major P source for cyanobacteria.

After a dinoflagellate-dominated spring bloom, more DOC can be expected to be released in the pelagic zone, based on sedimentation studies (Heiskanen, 1998). However, diatoms are generally high DOC producers, and they can excrete organic compounds leading to even higher DOC concentrations than dinoflagellate-dominated blooms (Spilling et al., 2014). There are species-specific differences in DOC excretion, and at least a part of the heterotrophic bacterial community is affected by the phytoplankton community composition (Bunse et al., 2016), affecting also the responses in bacterial production (Camarena-Gómez et al., 2018). There is thus a potential link between the phytoplankton community composition during spring and the early summer DOM pool, with the potential to affect the cyanobacterial blooms during summer. This link has so far not received much attention, and it is currently not taken into account in model predictions of $\mathrm{P}$ availability and cascading effects on cyanobacterial bloom development.

\section{A CONCEPTUAL MODEL}

In the relatively shallow coastal and shelf ecosystems, the pelagicbenthic coupling is more important for ecosystem functioning than in the deep oceans. Changes in the phytoplankton communities may consequently lead to spatial and temporal differences in the quantity and quality of organic matter input to the seafloor, which in turn is the main driver for biogeochemical cycling of electron acceptors and nutrients. The conceptual model presented in Figure 6 summarizes how different biogeochemical pathways may be altered by the phytoplankton community composition in the Baltic Sea, as described above. In particular, we represent the potential feedback mechanisms of changing plankton community in a typical site in the Gulf of Finland, characterized by seasonal sea ice and muddy, soft and oxic sediments inhabited by the two dominant macrozoobenthos species of soft bottom seabed, i.e., Marenzelleria spp. and Macoma baltica, which differentiate mostly by their different feeding habits, efficiency of bioturbation activities and location within sediments.

During harsh winters with a long ice season and thick ice cover, the sea-ice algal bloom typically dominated by diatoms is followed by a pelagic spring bloom of diatoms of similar species (e.g., Chaetoceros spp. T. baltica, and A. taeniata (Figures 6A,B). The bloom may be loosely grazed or degraded in the water column (up to 10\%, Lignell et al., 1993), but most of it sinks to the seafloor. Under oxic sediment conditions, this large pool of organic matter may be efficiently consumed by the macrozoobenthos. With ample food supply, the macrozoobenthos community might increase and improve the oxygen conditions in the sediments through bioturbation (Figure 6A). However, if the amount of settling material exceeds the threshold of being efficiently consumed by the bottom communities, the result is aggravated oxygen consumption leading to permanent or seasonal hypoxia (Norkko et al., 2012). This, in turn, may cause the local fauna to perish with obvious loss of biodiversity, and may lead to an efflux of $\mathrm{P}$ from the anoxic sediments, further enhancing the summer bloom of cyanobacteria (Figure 6B), and fuelling the vicious cycle of Vahtera et al. (2007a) (Figure 4).

During mild winters, with a thin ice cover and short duration, winter mixing conditions in the water column may enhance the germination of dinoflagellates cysts (Figure 6C). Depending on snow thickness combined with photoperiod, the sea-ice diatom bloom may be enhanced or reduced compared to that of harsh winter (Tedesco et al., 2017). In the case of favorable light conditions (e.g., snow-free or little snow on the ice cover), the sea-ice diatom bloom may be coupled to an under ice bloom of germinated dinoflagellates after the sea ice has completely melted. If the spring bloom would be mostly composed of $P$. catenata, this would be mostly degraded in the water column, becoming part of the phyto-detritus available to the macrozoobenthos, in particular to Marenzelleria. On oxic sediments and at high abundances, Marenzelleria may help keep the deep sediments oxygenated and the sinking organic matter remineralized without passing any of the sediment thresholds (Figure 6C). However, there might be situations when the sinking material is not efficiently consumed with the risk of seasonal hypoxia/anoxia. In the case of a spring bloom dominated by B. baltica, about $40-50 \%$ of the sinking POC would be composed of not easily degradable cysts (Figure 6D). On oxic sediments, the remaining part would be available as a source of food for the macrofauna. Of this non-degradable carbon pool, only $10-20 \%$ of the cysts may germinate in the following winter (Kremp and Anderson, 2000), thus $40-45 \%$ of this spring production would be buried in the sediment. This would represent an effective long-term C sink in the sediments (Figure 6D), which has the potential to improve the environmental status of the Baltic Sea.

Marine ecosystem models are currently essential tools for exploring the responses of ecosystems for management actions and for exploitation, but these models can only be useful if the ecological processes are correctly described and the essential components are included. In order to develop and improve this approach, understanding the transfer of nutrients between pelagic and benthic systems from winter through spring and 


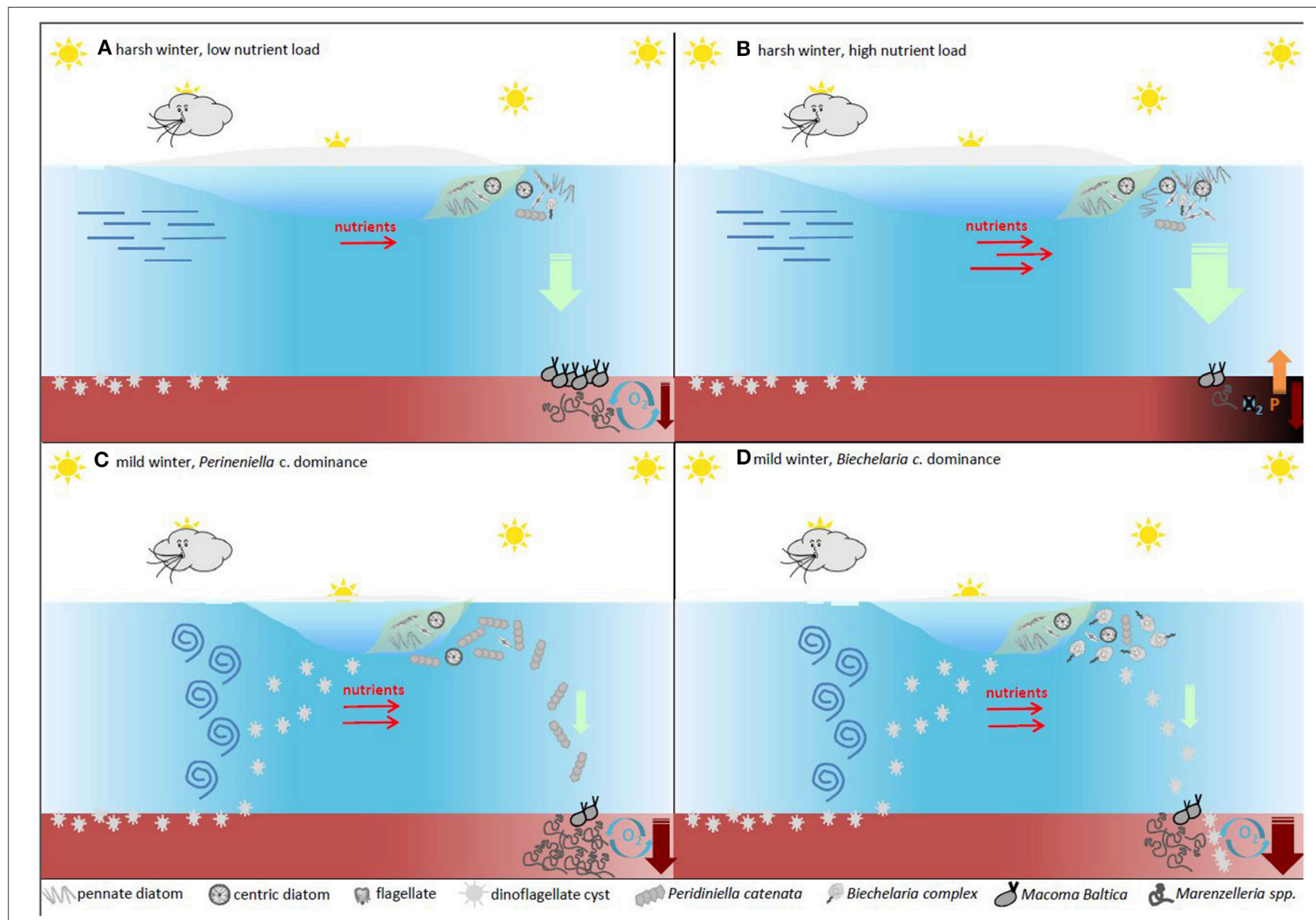

FIGURE 6 | A conceptual model of how the main spring phytoplankton groups affect sedimentation patterns and biogeochemical cycling of nutrients. The primary driver for the onset of the spring bloom is the availability of light, which is mainly governed by the mixing/stabilization of the upper parts of the water column. In the Baltic Sea large outflow of freshwater during spring creates patches of stratified water where the bloom initiates. After the spring bloom, diatoms tend to sink quickly to the seafloor where the biomass is remineralized. The sediment processes will depend on the amount of settling material and eutrophication have shifted the pristine state (A) towards a deteriorated environmental state with release of nutrients from the sediments (B). Dinoflagellates on the other hand tend to lyse before reaching the sediment $\mathbf{( C )}$ with the exception of resting cysts (D). These resting stages (some species of diatoms also produce large quantities of resting stages with the same function) are built for long term survival and are not remineralized in the sediment on a seasonal basis. Some of the resting stages are buried in the seafloor, providing a biological sink for organic nutrients. The size of this sink largely depends on the species composition of phytoplankton during the productive spring bloom.

into summer is needed. There are open questions related to the role of DOM in transfer of nutrients (quantity and quality), and the qualitative aspect of the sinking material, where changes in functional traits in the spring bloom community is important. The potential feedback mechanisms through changing plankton community composition have so far received relatively little attention, although community structure is known to play a major role for biogeochemical fluxes. The inherent difficulty in resolving causal connections from field observations calls for more dedicated experiments addressing the plankton community composition and the settling of phytoplankton in various forms under different environmental change scenarios.

Finally, as the Baltic Sea is facing increasing temperature associated with shorter ice season and thinner sea ice (Thomas et al., 2017), there are indications that climate change will weaken the magnitude, but prolong the duration of the spring bloom (Groetsch et al., 2016), which would directly affect the timing and flux of organic matter to the seafloor (Tamelander et al., 2017). Earlier stratification could benefit dinoflagellates, and the observed shift toward more dinoflagellate dominance in Gulf of Finland could continue and expand spatially. This would affect both the quantity and quality of the settling material and its mineralization at the seafloor, with less seabed enrichment in labile organic matter due to a more efficient pelagic microbial loop (Figure 6C). Dominance of species with high encystment rates and low germination success may enhance long-term burial of organic carbon as more resting stages are settling out of the water column (Figure 6D). This would functions as a biological sink and could be an underlying explanation for part of the unresolved N-burial (Jäntti and Hietanen, 2012), but this has not to our knowledge been tested before. Increasing 
burial would diminish available nutrients in the ecosystem and would together with the realized reduction in nutrient loading counteract the observed spreading of the eutrophication. The increasing contribution of cyst-producing dinoflagellates could thus contribute to reversing eutrophication in the Baltic Sea.

\section{AUTHOR CONTRIBUTIONS}

The original idea for this manuscript came from a project involving KS, AK, and TiT. KO carried out data analysis on the Helsinki data (Figures 2, 3). KO, AK, and RK formulated the phytoplankton species section and its development, and RK made Figure 1 modified by KS. JL wrote the sediment process section and helped formulate the modified vicious cycle (Figure 4). LT, HP, KS, and TiT developed the conceptual model and LT made Figure 5. ToT reviewed and wrote about the trends in sedimentation. KS wrote the

\section{REFERENCES}

Adam, B., Klawonn, I., Svedén, J. B., Bergkvist, J., Nahar, N., Walve, J., et al. (2016). $\mathrm{N}_{2}$-fixation, ammonium release and $\mathrm{N}$-transfer to the microbial and classical food web within a plankton community. ISME J. 10, 450-459. doi: 10.1038/ismej.2015.126

Ahlgren, J., Reitzel, K., Tranvik, L., Gogoll, A., and Rydin, E. (2006). Degradation of organic phosphorus compounds in anoxic Baltic Sea sediments: a ${ }^{31} \mathrm{P}$ nuclear magnetic resonance study. Limnol. Oceanogr. 51, 2341-2348. doi: 10.4319/lo.2006.51.5.2341

Aigars, J., Poikane, R., Dalsgaard, T., Eglite, E., and Jansons, M. (2015). Biogeochemistry of N, P and Si in the Gulf of Riga surface sediments: implications of seasonally changing factors. Cont. Shelf Res. 105, 112-120. doi: 10.1016/j.csr.2015.06.008

Almroth-Rosell, E., Eilola, K., Kuznetsov, I., Hall, P. O. J., and Meier, H. E. M. (2015). A new approach to model oxygen dependent benthic phosphate fluxes in the Baltic Sea. J. Mar. Syst. 144, 127-141. doi: 10.1016/j.jmarsys.2014.11.007

Anderson, T. R., and Ducklow, H. W. (2001). Microbial loop carbon cycling in ocean environments studied using a simple steady-state model. Aquat. Microb. Ecol. 26, 37-49. doi: 10.3354/ame026037

Andersson, A., Brugel, S., Paczkowska, J., Rowe, O., Figueroa, D., Kratzer, S., et al. (2018). Influence of allochthonous dissolved organic matter on pelagic basal production in a northerly estuary. Estuar. Coast. Shelf Sci. 204, 225-235. doi: 10.1016/j.ecss.2018.02.032

Andersson, A., Meier, H. M., Ripszam, M., Rowe, O., Wikner, J., Haglund, P., et al. (2015). Projected future climate change and Baltic Sea ecosystem management. Ambio 44, 345-356. doi: 10.1007/s13280-015-0654-8

Asmala, E., Autio, R., Kaartokallio, H., Pitkänen, L., Stedmon, C., and Thomas, D. (2013). Bioavailability of riverine dissolved organic matter in three Baltic Sea estuaries and the effect of catchment land use. Biogeosciences 10, 6969-6986. doi: 10.5194/bg-10-6969-2013

BACCI (2015). Second Assessment of Climate Change for the Baltic Sea Basin. New York, NY: SpringerOpen.

Baines, S. B., and Pace, M. L. (1991). The production of dissolved organic matter by phytoplankton and its importance to bacteria: patterns across marine and freshwater systems. Limnol. Oceanogr. 36, 1078-1090. doi: 10.4319/lo.1991.36.6.1078

Belkin, I. M. (2009). Rapid warming of large marine ecosystems. Prog. Oceanogr. 81, 207-213. doi: 10.1016/j.pocean.2009.04.011

Berner, R. A. (1974). "Kinetic models for the early diagenesis of nitrogen, sulphur, phosphorus, and silicon in anoxic marine sediments," in The Sea, Vol. 5, Marine Chemistry, ed E. D. Goldberg (New York, NY: John Wiley and Sons), 427-450.

Blomqvist, S., Gunnars, A., and Elmgren, R. (2004). Why the limiting nutrient differs between temperate coastal seas and freshwater lakes: a matter of salt. Limnol. Oceanogr. 49, 2236-2241. doi: 10.4319/lo.2004.49.6.2236 manuscript with contributions and/or comments from all co-authors.

\section{FUNDING}

This study was supported by the Academy of Finland (decisions no 259164 and 263376) and Estonian Research Council (no 1575P, KO). Further funding came from Walter and Andrée de Nottbeck Foundation (KS and ToT) and the Swedish Cultural Heritage (ToT). LT acknowledges support also from COCOANutrient cocktail in coastal zones of the Baltic Sea-EU BONUS project.

\section{ACKNOWLEDGMENTS}

We are thankful to the City of Helsinki Environment Center (Finland) for providing the phytoplankton monitoring data.

Brzezinski, M. A., Olson, R. J., and Chisholm, S. W. (1990). Silicon availability and cell-cycle progression in marine diatoms. Mar. Ecol. Prog. Ser. 67, 83-96. doi: 10.3354/meps067083

Bunse, C., Bertos-Fortis, M., Sassenhagen, I., Sildever, S., Sjöqvist, C., Godhe, A., et al. (2016). Spatio-temporal interdependence of bacteria and phytoplankton during a Baltic Sea spring bloom. Front. Microbiol. 7:517. doi: $10.3389 /$ fmicb.2016.00517

Camarena-Gómez, M. T., Lipsewers, T., Piiparinen, J., Eronen-Rasimus, E., Perez-Quemaliños, D., Hoikkala, L., et al. (2018). Shifts in phytoplankton community structure modify bacterial production, abundance and community composition. Aquat. Microb. Ecol. 81, 149-170. doi: 10.3354/ame01868

Canfield, D. E., Thamdrup, B., and Kristensen, E. (2005). Aquatic Geomicrobiology, Advances in Marine Biology. London: Elsevier Academic Press.

Carlsson, P., and Graneli, E. (1998). "Utilization of dissolved organic matter (DOM) by phytoplankton, including harmful species," in Physiology of Harmful Algal Blooms. NATO ASI Series G41, eds D. M. Anderson, A. D. Cembella, and G. M. Hallegraeff (Berlin: Springer-Verlag), 509-524.

Carstensen, J., Conley, D. J., Bonsdorff, E., Gustafsson, B. G., Hietanen, S., Janas, U., et al. (2014). Hypoxia in the Baltic Sea: biogeochemical cycles, benthic fauna, and management. Ambio 43, 26-36. doi: 10.1007/s13280-013-0474-7

Cloern, J. E. (2001). Our evolving conceptual model of the coastal eutrophication problem. Mar. Ecol. Prog. Ser. 210, 223-253. doi: 10.3354/meps2 10223

Conley, D. J., Carstensen, J., Aigars, J., Axe, P., Bonsdorff, E., Eremina, T., et al. (2011). Hypoxia is increasing in the coastal zone of the Baltic Sea. Environ. Sci. Technol. 45, 6777-6783. doi: 10.1021/es201212r

Conley, D. J., Humborg, C., Rahm, L., Savchuk, O. P., and Wulff, F. (2002). Hypoxia in the Baltic Sea and basin-scale changes in phosphorus biogeochemistry. Environ. Sci. Technol. 36, 5315-5320. doi: 10.1021/es02 $5763 \mathrm{w}$

Conley, D. J., Schelske, C. L., and Stoermer, E. F. (1993). Modification of the biogeochemical cycle of silica with eutrophication. Mar. Ecol. Prog. Ser. 101, 179-192. doi: 10.3354/meps101179

Dalsgaard, T., De Brabandere, L., and Hall, P. O. (2013). Denitrification in the water column of the central Baltic Sea. Geochim. Cosmochim. Acta 106, 247-260. doi: 10.1016/j.gca.2012.12.038

Danielsson, Å., Papush, L., and Rahm, L. (2008). Alterations in nutrient limitations - scenarios of a changing Baltic Sea. J. Mar. Syst. 73, 263-283. doi: 10.1016/j.jmarsys.2007.10.015

Darecki, M., and Stramski, D. (2004). An evaluation of MODIS and SeaWiFS bio-optical algorithms in the Baltic Sea. Remote Sens. Environ. 89, 326-350. doi: $10.1016 /$ j.rse.2003.10.012

Doney, S. C. (1997). The ocean's productive deserts. Nature 389, 905-906. doi: $10.1038 / 39993$ 
Duarte, C. M. (2014). Global change and the future ocean: a grand challenge for marine sciences. Front. Mar. Sci. 1:63. doi: 10.3389/fmars.2014.00063

Egge, J. K., and Aksnes, D. L. (1992). Silicate as regulating nutrient in phytoplankton competition. Mar. Ecol. Prog. Ser. 83, 281-289. doi: 10.3354/meps 083281

Egger, M., Jilbert, T., Behrends, T., Rivard, C., and Slomp, C. P. (2015). Vivianite is a major sink for phosphorus in methanogenic coastal surface sediments. Geochim. Cosmochim. Acta 169, 217-235. doi: 10.1016/j.gca.2015. 09.012

Einsele, W. (1938). Über chemische und kolloidchemische Vorgänge in Eisen-Phosphat-Systemen unter limnochemischen und limnogeologischen Gesichtspunkten. Arch. Hydrobiol. 33, 361-387.

Elmgren, R., Blenckner, T., and Andersson, A. (2015). Baltic Sea management: successes and failures. Ambio 44, 335-344. doi: 10.1007/s13280-015-0653-9

Fennel, W., and Neumann, T. (2014). Introduction to the Modelling of Marine Ecosystems. Amsterdam: Elsevier.

Froelich, P. N., Klinkhammer, G. P., Bender, M. L., Luedtke, N. A., Heath, G. R., Cullen, D., et al. (1979). Early oxidation of org. matter in pelagic sediments of the eastern equatorial Atlantic: suboxic diagenesis. Geochim. Cosmochim. Acta 43, 1075-1090. doi: 10.1016/0016-7037(79)90095-4

Gilpin, L. C., Davidson, K., and Roberts, E. (2004). The influence of changes in nitrogen: silicon ratios on diatom growth dynamics. J. Sea Res. 51, 21-35. doi: 10.1016/j.seares.2003.05.005

Groetsch, P. M. M., Simis, S. G. H., Eleveld, M. A., and Peters, S. W. M. (2016). Spring blooms in the Baltic Sea have weakened but lengthened from 2000 to 2014. Biogeosciences 13, 4959-4973. doi: 10.5194/bg-13-4959-2016

Gustafsson, B. G., Schenk, F., Blenckner, T., Eilola, K., Meier, H. M., Müller-Karulis, B., et al. (2012). Reconstructing the development of Baltic Sea eutrophication 1850-2006. Ambio 41, 534-548. doi: $10.1007 / \mathrm{s} 13280-012-0318-\mathrm{x}$

Hagström, Å., Azam, F., Kuparinen, J., and Zweifel, U.-L. (2001). “Pelagic plankton growth and resource limitations in the Baltic Sea," in A Systems Analysis of the Baltic Sea (Berlin: Springer), 177-210.

Hajdu, S., Höglander, H., and Larsson, U. (2007). Phytoplankton vertical distributions and composition in Baltic Sea cyanobacterial blooms. Harmful Algae 6, 189-205. doi: 10.1016/j.hal.2006.07.006

Hallegraeff, G. M. (2010). Ocean climate change, phytoplankton community responses, and harmful algal blooms: a formidable predictive challenge. J. Phycol. 46, 220-235. doi: 10.1111/j.1529-8817.2010.00815.x

Halpern, B. S., Walbridge, S., Selkoe, K. A., Kappel, C. V., Micheli, F., D’Agrosa, C., et al. (2008). A global map of human impact on marine ecosystems. Science 319, 948-952. doi: 10.1126/science.1149345

Härnström, K., Ellegaard, M., Andersen, T. J., and Godhe, A. (2011). Hundred years of genetic structure in a sediment revived diatom population. Proc. Natl. Acad. Sci. U.S.A. 108, 4252-4257. doi: 10.1073/pnas.1013528108

Havenhand, J. N. (2012). How will ocean acidification affect Baltic Sea ecosystems? an assessment of plausible impacts on key functional groups. Ambio 41, 637-644. doi: 10.1007/s13280-012-0326-x

Heiskanen, A. S. (1993). Mass encystment and sinking of dinoflagellates during a spring bloom. Mar. Biol. 116, 161-167. doi: 10.1007/BF00350743

Heiskanen, A. S. (1995). Contamination of sediment trap fluxes by vertically migrating phototrophic microoranisms in the coastal Baltic Sea. Mar. Ecol. Prog. Ser. 122, 45-58. doi: 10.3354/meps 122045

Heiskanen, A. S. (1998). Factors governing sedimentation and pelagic nutrient cycles in the northern Baltic Sea. Monogr. Boreal. Env. Res. 8, 1-80.

Heiskanen, A. S., and Kononen, K. (1994). Sedimentation of vernal and late summer phytoplankton communities in the coastal Baltic Sea. Arch. Hydrobiol. $131,175-198$.

HELCOM (2009). "Eutropication in the Baltic Sea - an integrated thematic assessment of the effects of nutrient enrichment and eutrophication in the Baltic Sea region," in Baltic Sea Environment Proceedings (Helsinki: Helsinki Commission).

HELCOM (2010). "Hazardous substances in the Baltic Sea - an integrated thematic assessment of hazardous substances in the Baltic Sea," in Balt Sea Environment Proceedings (Helsinki: Helsinki Commission).

Hietanen, S., and Kuparinen, J. (2008). Seasonal and short-term variation in denitrification and anammox at a coastal station on the Gulf of Finland, Baltic Sea. Hydrobiologia 596, 67-77. doi: 10.1007/s10750-007-9058-5
Hinder, S. L., Hays, G. C., Edwards, M., Roberts, E. C., Walne, A. W., and Gravenor, M. B. (2012). Changes in marine dinoflagellate and diatom abundance under climate change. Nat. Clim. Change 2, 271-275. doi: 10.1038/nclimate1388

Höglander, H., Larsson, U., and Hajdu, S. (2004). Vertical distribution and settling of spring phytoplankton in the offshore NW Baltic Sea proper. Mar. Ecol. Prog. Ser. 283, 15-27. doi: 10.3354/meps283015

Hoikkala, L., Kortelainen, P., Soinne, H., and Kuosa, H. (2015). Dissolved organic matter in the Baltic Sea. J. Mar. Syst. 142, 47-61. doi: 10.1016/j.jmarsys.2014.10.005

Hoikkala, L., Lahtinen, T., Perttilä, M., and Lignell, R. (2012). Seasonal dynamics of dissolved organic matter on a coastal salinity gradient in the northern Baltic Sea. Cont. Shelf Res. 45, 1-14. doi: 10.1016/j.csr.2012.04.008

Hoikkala, L., Tammert, H., Lignell, R., Eronen-Rasimus, E., Spilling, K., and Kisand, V. (2016). Autochthonous dissolved organic matter drives bacterial community composition during a bloom of filamentous cyanobacteria. Front. Mar. Sci. 3:111. doi: 10.3389/fmars.2016.00111

Hordoir, R., and Meier, H. (2012). Effect of climate change on the thermal stratification of the Baltic Sea: a sensitivity experiment. Clim. Dyn. 38, 1703-1713. doi: 10.1007/s00382-011-1036-y

Humborg, C., Smedberg, E., Medina, M. R., and Mörth, C.-M. (2008). Changes in dissolved silicate loads to the Baltic Sea-the effects of lakes and reservoirs. J. Mar. Syst. 73, 223-235. doi: 10.1016/j.jmarsys.2007.10.014

Ikävalko, J., and Thomsen, H. A. (1997). The Baltic Sea ice biota (March 1994): a study of the protistan community. Eur. J. Protistol. 33, 229-243. doi: 10.1016/S0932-4739(97)80001-6

Jaanus, A., Hajdu, S., Kaitala, S., Andersson, A., Kaljurand, K., Ledaine, I., et al. (2006). Distribution patterns of isomorphic cold-water dinoflagellates (Scrippsiella/Woloszynskia complex) causing 'red tides' in the Baltic Sea. Hydrobiologia 554, 137-146. doi: 10.1007/s10750-005-1014-7

Jäntti, H., and Hietanen, S. (2012). The effects of hypoxia on sediment nitrogen cycling in the Baltic Sea. Ambio 41, 161-169. doi: 10.1007/s13280-0110233-6

Jilbert, T., Slomp, C. P., Gustafsson, B. G., and Boer, W. (2011). Beyond the Fe-Predox connection: preferential regeneration of phosphorus from organic matter as a key control on Baltic Sea nutrient cycles. Biogeosciences 8, 1699-1720. doi: 10.5194/bg-8-1699-2011

Jurgensone, I., and Aigars, J. (2012). Bioavailability of riverine dissolved organic matter to phytoplankton in the marine coastal waters. Estuar. Coast. Shelf Sci. 107, 97-104. doi: 10.1016/j.ecss.2012.05.005

Kahru, M., Elmgren, R., and Savchuk, O. P. (2016). Changing seasonality of the Baltic Sea. Biogeosciences 13, 1009-1018. doi: 10.5194/bg-13-1009-2016

Kahru, M., Leppänen, J. M., Nômmann, S., Passow, U., Postel, L., and Schulz, S. (1990). Spatio-temporal mosaic of the phytoplankton spring bloom in the open Baltic Sea in 1986. Mar. Ecol. Prog. Ser. 66, 301-309. doi: 10.3354/meps0 66301

Kahru, M., and Nõmmann, S. (1990). The phytoplankton spring bloom in the Baltic Sea in 1985, 1986 - multitude of spatiotemporal scales. Cont. Shelf Res. 10, 329-354. doi: 10.1016/0278-4343(90)90055-Q

Kangro, K., Olli, K., Tamminen, T., and Lignell, R. (2007). Species-specific responses of a cyanobacteria-dominated phytoplankton community to artificial nutrient limitation in the Baltic Sea. Mar. Ecol. Prog. Ser. 336, 15-27. doi: $10.3354 /$ meps 336015

Kazamia, E., Czesnick, H., Nguyen, T. T. V., Croft, M. T., Sherwood, E., Sasso, S., et al. (2012). Mutualistic interactions between vitamin B12-dependent algae and heterotrophic bacteria exhibit regulation. Environ. Microbiol. 14, 1466-1476. doi: 10.1111/j.1462-2920.2012.02733.x

Kiirikki, M., Lehtoranta, J., Inkala, A., Pitkänen, H., Hietanen, S., Hall, P. O. J., et al. (2006). A simple sediment process description suitable for 3D-ecosystem modelling - development and testing in the Gulf of Finland. J. Mar. Syst. 61, 55-66. doi: 10.1016/j.jmarsys.2006.02.008

Klais, R., Tamminen, T., Kremp, A., Spilling, K., An, B. W., Hajdu, S., et al. (2013). Spring phytoplankton communities shaped by interannual weather variability and dispersal limitation: mechanisms of climate change effects on key coastal primary producers. Limnol. Oceanogr. 58, 753-762. doi: 10.4319/lo.2013.58.2.0753

Klais, R., Tamminen, T., Kremp, A., Spilling, K., and Olli, K. (2011). Decadalscale changes of dinoflagellates and diatoms in the anomalous Baltic Sea spring bloom. PLoS ONE 6:e21567. doi: 10.1371/journal.pone.0021567 
Klawonn, I., Nahar, N., Walve, J., Andersson, B., Olofsson, M., Svedén, J., et al. (2016). Cell-specific nitrogen-and carbon-fixation of cyanobacteria in a temperate marine system (Baltic Sea). Environ. Microbiol. 18, 4596-4609. doi: $10.1111 / 1462-2920.13557$

Korth, F., Deutsch, B., Liskow, I., and Voss, M. (2012). Uptake of dissolved organic nitrogen by size-fractionated plankton along a salinity gradient from the North Sea to the Baltic Sea. Biogeochemistry 111, 347-360. doi: 10.1007/s10533-011-9656-1

Kremp, A. (2000). Morphology and germination pattern of the resting cyst of Peridiniella catenata (Dinophycea) from the Baltic Sea. Phycologia 39, 183-186. doi: 10.2216/i0031-8884-39-3-183.1

Kremp, A., and Anderson, D. M. (2000). Factors regulating germination of resting cysts of the spring bloom dinoflagellate Scrippsiella hangoei from the northern Baltic Sea. J. Plankton Res. 22, 1311-1327. doi: 10.1093/plankt/22.7.1311

Kremp, A., Elbrächter, M., Schweikert, M., Wolny, J. L., and Gottschling, M. (2005). Woloszynskia halophila (Biecheler) comb. nov.: a bloom-forming coldwater dinoflagellate co-occurring with Scrippsiella hangoei (Dinophyceae) in the Baltic Sea. J. Phycol. 41, 629-642. doi: 10.1111/j.1529-8817.2005.00070.x

Kremp, A., Hinners, J., Klais, R., Leppänen, A.-P., and Kallio, A. (2018). Patterns of vertical cyst distribution and survival in 100-year-old sediment archives of three spring dinoflagellate species from the Northern Baltic Sea. Eur. J. Phycol. 53, 1-11. doi: 10.1080/09670262.2017.1386330

Kremp, A., Rengefors, K., and Montresorc, M. (2009). Species specific encystment patterns in three Baltic cold-water dinoflagellates: the role of multiple cues in resting cyst formation. Limnol. Oceanogr. 54, 1125-1138. doi: $10.4319 /$ lo.2009.54.4.1125

Kremp, A., Tamminen, T., and Spilling, K. (2008). Dinoflagellate bloom formation in natural assemblages with diatoms: nutrient competition and growth strategies in Baltic spring phytoplankton. Aquat. Microb. Ecol. 50, 181-196. doi: $10.3354 /$ ame01163

Kuosa, H., Autio, R., Kuuppo, P., Setala, O., and Tanskanen, S. (1997). Nitrogen, silicon and zooplankton controlling the Baltic spring bloom: an experimental study. Estuar. Coast. Shelf Sci. 45, 813-821. doi: 10.1006/ecss.1997.0241

Kuypers, M. M., Sliekers, A. O., Lavik, G., Schmid, M., Jørgensen, B. B., Kuenen, J. G., et al. (2003). Anaerobic ammonium oxidation by anammox bacteria in the Black Sea. Nature 422, 608-611. doi: 10.1038/nature01472

Larsen, J., Kuosa, H., Ikävalko, J., Kivi, K., and Hällfors, S. (1995). A redescription of Scrippsiella hangoei (Schiller) Comb-Nov - a red tide dinoflagellate from the northern Baltic. Phycologia 34, 135-144. doi: 10.2216/i0031-8884-34-2135.1

Larsson, U., Hajdu, S., Walve, J., and Elmgren, R. (2001). Baltic Sea nitrogen fixation estimated from the summer increase in upper mixed layer total nitrogen. Limnol. Oceanogr. 46, 811-820. doi: 10.4319/lo.2001.46.4. 0811

Legrand, C., and Carlsson, P. (1998). Uptake of high molecular weight dextran by the dinoflagellate Alexandrium catenella. Aquat. Microb. Ecol. 16, 81-86. doi: $10.3354 /$ ame016081

Lehtoranta, J., Ekholm, P., and Pitkänen, H. (2008). Eutrophication-driven sediment microbial processes can explain the regional variation in phosphorus concentrations between Baltic Sea sub-basins. J. Mar. Syst. 74, 495-504. doi: 10.1016/j.jmarsys.2008.04.001

Lehtoranta, J., Ekholm, P., and Pitkänen, H. (2009). Coastal eutrophication thresholds: a matter of sediment microbial processes. Ambio 38, 303-308. doi: 10.1579/09-A-656.1

Lehtoranta, J., and Heiskanen, A. S. (2003). Dissolved iron: phosphate ratio as an indicator of phosphate release to oxic water of the inner and outer coastal Baltic Sea. Hydrobiologia 492, 69-84. doi: 10.1023/A:1024822013580

Lehtoranta, J., Savchuk, O. P., Elken, J., Dahlbo, K., Kuosa, H., Raateoja, M., et al. (2017). Atmospheric forcing controlling inter-annual nutrient dynamics in the open Gulf of Finland. J. Mar. Syst. 171, 4-20. doi: 10.1016/j.jmarsys.2017. 02.001

Leterme, S. C., Edwards, M., Seuront, L., Attrill, M., Reid, P., and John, A. (2005). Decadal basin-scale changes in diatoms, dinoflagellates, and phytoplankton color across the North Atlantic. Limnol. Oceanogr. 50, 1244-1253. doi: 10.4319/lo.2005.50.4.1244

Lignell, R., Heiskanen, A. S., Kuosa, H., Gundersen, K., Kuuppo-Leinikki, P., Pajuniemi, R., et al. (1993). Fate of a phytoplankton spring bloom - sedimentation and carbon flow in the planktonic food web in the northern Baltic. Mar. Ecol. Prog. Ser. 94, 239-252. doi: 10.3354/meps0 94239

Lignell, R., Kaitala, S., and Kuosa, H. (1992). Factors controlling phyto- and bacterioplankton in late spring on a salinity gradient in the northern Baltic. Mar. Ecol. Prog. Ser. 84, 121-131. doi: 10.3354/meps084121

Litchman, E., and Klausmeier, C. A. (2008). Trait-based community ecology of phytoplankton. Annu. Rev. Ecol. Evol. Syst. 39, 615-639. doi: 10.1146/annurev.ecolsys.39.110707.173549

Lundberg, C., Jakobsson, B.-M., and Bonsdorff, E. (2009). The spreading of eutrophication in the eastern coast of the Gulf of Bothnia, northern Baltic Sea-an analysis in time and space. Estuar. Coast. Shelf Sci. 82, 152-160. doi: 10.1016/j.ecss.2009.01.005

Martin-Jézéquel, V., Hildebrand, M., and Brzezinski, M. A. (2000). Silicon metabolism in diatoms: implications for growth. J. Phycol. 36, 821-840. doi: 10.1046/j.1529-8817.2000.00019.x

Maximov, A., Bonsdorff, E., Eremina, T., Kauppi, L., Norkko, A., and Norkko, J. (2015). Context-dependent consequences of Marenzelleria spp. (Spionidae: Polychaeta) invasion for nutrient cycling in the Northern Baltic Sea. Oceanologia 57, 342-348. doi: 10.1016/j.oceano.2015.06.002

Meier, H. M., Andersson, H. C., Arheimer, B., Donnelly, C., Eilola, K., Gustafsson, B. G., et al. (2014). Ensemble modeling of the Baltic Sea ecosystem to provide scenarios for management. Ambio 43, 37-48. doi: 10.1007/s13280-013-0475-6

Mercado, J. M., Cortés, D., García, A., and Ramírez, T. (2007). Seasonal and inter-annual changes in the planktonic communities of the northwest Alboran Sea (Mediterranean Sea). Prog. Oceanogr. 74, 273-293. doi: $10.1016 /$ j.pocean.2007.04.013

Moestrup, Ø., Lindberg, K., and Daugbjerg, N. (2009). Studies on woloszynskioid dinoflagellates IV: the genus Biecheleria gen. nov. Phycol. Res. 57, 203-220. doi: 10.1111/j.1440-1835.2009.00540.x

Mohrholz, V., Naumann, M., Nausch, G., Kruger, S., and Grawe, U. (2015). Fresh oxygen for the Baltic Sea - an exceptional saline inflow after a decade of stagnation. J. Mar. Syst. 148, 152-166. doi: 10.1016/j.jmarsys.2015.03.005

Nausch, M., and Nausch, G. (2004). Bacterial utilization of phosphorus pools after nitrogen and carbon amendment and its relation to alkaline phosphatase activity. Aquat. Microb. Ecol. 37, 237-245. doi: 10.3354/ame037237

Nausch, M., Nausch, G., Wasmund, N., and Nagel, K. (2008). Phosphorus pool variations and their relation to cyanobacteria development in the Baltic Sea: a three-year study. J. Mar. Syst. 71, 99-111. doi: 10.1016/j.jmarsys.2007.06.004

Niemi, A. (1975). Ecology of phytoplankton in the Tvärminne area, SW coast of Finland. II. Primary production and environmental conditions in the archipelago and the sea zone. Acta Bot. Fenn. 105, 1-73.

Niemi, A. (1979). Blue-green algal blooms and N:P ratio in the Baltic Sea. Acta Bot. Fenn. 110, 57-61.

Niiranen, S., Yletyinen, J., Tomczak, M. T., Blenckner, T., Hjerne, O., MacKenzie, B. R., et al. (2013). Combined effects of global climate change and regional ecosystem drivers on an exploited marine food web. Glob. Change Biol. 19, 3327-3342. doi: 10.1111/gcb.12309

Norkko, J., Reed, D. C., Timmermann, K., Norkko, A., Gustafsson, B. G., Bonsdorff, E., et al. (2012). A welcome can of worms? hypoxia mitigation by an invasive species. Glob. Change Biol. 18, 422-434. doi: 10.1111/j.1365-2486.2011.02513.x

Officer, C. B., and Ryther, J. H. (1980). The possible importance of silicon in marine eutrophication. Mar. Ecol. Prog. Ser. 3, 75-87. doi: 10.3354/meps003083

Olli, K., Clarke, A., Danielsson, A., Aigars, J., Conley, D. J., and Tamminen, T. (2008). Diatom stratigraphy and long-term dissolved silica concentrations in the Baltic Sea. J. Mar. Syst. 73, 284-299. doi: 10.1016/j.jmarsys.2007.04.009

Olli, K., and Heiskanen, A.-S. (1999). Seasonal stages of phytoplankton community structure and sinking loss in the Gulf of Riga. J. Mar. Syst. 23, 165-184. doi: 10.1016/S0924-7963(99)00056-1

Olli, K., Heiskanen, A. S., and Lohikari, K. (1998). Vertical migration of autotrophic micro-organisms during a vernal bloom at the coastal Baltic Sea - coexistence through niche separation. Hydrobiologia 363, 179-189. doi: 10.1007/978-94-017-1493-8_14

Olli, K., Klais, R., Tamminen, T., Ptacnik, R., and Andersen, T. (2011). Long term changes in the Baltic Sea phytoplankton community. Boreal Env. Res. 16, 3-14.

Olli, K., and Trunov, K. (2010). Abundance and distribution of vernal bloom dinoflagellate cysts in the Gulf of Finland and Gulf of Riga (the Baltic Sea). Deep Sea Res. II 57, 235-242. doi: 10.1016/j.dsr2.2009.09.009 
Olsen, S., and Paasche, E. (1986). Variable kinetics of silicon -limited growth in Thalassiosira pseudonana (Bacillariophyceae) in response to changed chemical composition of the growth medium. Br. Phycol. J. 21, 183-190. doi: 10.1080/00071618600650211

Omstedt, A., Humborg, C., Pempkowiak, J., Perttilä, M., Rutgersson, A., Schneider, B., et al. (2014). Biogeochemical control of the coupled $\mathrm{CO}_{2}-\mathrm{O}_{2}$ system of the Baltic Sea: a review of the results of Baltic-C. Ambio 43, 49-59. doi: 10.1007/s13280-013-0485-4

Papush, L., and Danielsson, $\AA$. (2006). Silicon in the marine environment: dissolved silica trends in the Baltic Sea. Estuar. Coast. Shelf Sci. 67, 53-66. doi: 10.1016/j.ecss.2005.09.017

Papush, L., Danielsson, Å., and Rahm, L. (2009). Dissolved silica budget for the Baltic Sea. J. Sea Res. 62, 31-41. doi: 10.1016/j.seares.2009.03.001

Pitkänen, H., Lehtoranta, J., and Räike, A. (2001). Internal nutrient fluxes couteract decreases in external load: the case of the estuarial eastern Gulf of Finland, Baltic Sea. Ambio 30, 195-201. doi: 10.1579/0044-7447-30.4.195

Raateoja, M., Kuosa, H., and Hällfors, S. (2011). Fate of excess phosphorus in the Baltic Sea: a real driving force for cyanobacterial blooms? J. Sea Res. 65, 315-321. doi: 10.1016/j.seares.2011.01.004

Raateoja, M., Seppälä, J., Kuosa, H., and Myrberg, K. (2005). Recent changes in trophic state of the Baltic Sea along SW coast of Finland. Ambio 34, 188-191. doi: 10.1579/0044-7447-34.3.188

Reynolds, C. S. (2006). Ecology of Phytoplankton. Cambridge: Cambridge University Press. doi: 10.1017/CBO9780511542145

Rintala, J.-M., Spilling, K., and Blomster, J. (2007). Temporary cyst enables longterm dark survival of Scrippsiella hangoei (Dinophyceae). Mar. Biol. 152, 57-62. doi: $10.1007 / \mathrm{s} 00227-007-0652-\mathrm{x}$

Rolff, C., and Elfwing, T. (2015). Increasing nitrogen limitation in the Bothnian Sea, potentially caused by inflow of phosphate-rich water from the Baltic Proper. Ambio 44, 601-611. doi: 10.1007/s13280-015-0675-3

Rysgaard, S., Fossing, H., and Jensen, M. M. (2001). Organic matter degradation through oxygen respiration, denitrification, and manganese, iron, and sulfate reduction in marine sediments (the Kattegat and the Skagerrak). Ophelia 55, 77-91. doi: 10.1080/00785236.2001.10409475

Savchuk, O. P. (2005). Resolving the Baltic Sea into seven subbasins: N and P budgets for 1991-1999. J. Mar. Syst. 56, 1-15. doi: 10.1016/j.jmarsys.2004.08.005

Schelske, C. L., and Stoermer, E. F. (1971). Eutrophication, silica depletion, and predicted changes in algal quality in Lake Michigan. Science 173, 423-424.

Seidel, M., Manecki, M., Herlemann, D. P., Deutsch, B., Schulz-Bull, D., Jürgens, K., et al. (2017). Composition and transformation of dissolved organic matter in the Baltic Sea. Front. Earth Sci. 5:31. doi: 10.3389/feart.2017.00031

Simis, S. G. H., Ylöstalo, P., Kallio, K., Spilling, K., and Kutser, T. (2017). Contrasting seasonality in optical-biogeochemical properties of the Baltic Sea. PLoS ONE 12:e0173357. doi: 10.1371/journal.pone.0173357

Sjöqvist, C., Godhe, A., Jonsson, P., Sundqvist, L., and Kremp, A. (2015). Local adaptation and oceanographic connectivity patterns explain genetic differentiation of a marine diatom across the North Sea-Baltic Sea salinity gradient. Mol. Ecol. 24, 2871-2885. doi: 10.1111/mec.13208

Slomp, C. P., Mort, H. P., Jilbert, T., Reed, D. C., Gustafsson, B. G., and Wolthers, M. (2013). Coupled dynamics of iron and phosphorus in sediments of an oligotrophic coastal basin and the impact of anaerobic oxidation of methane. PLoS ONE 8:e62386. doi: 10.1371/journal.pone.0062386

Smayda, T. J., and Reynolds, C. S. (2003). Strategies of marine dinoflagellate survival and some rules of assembly. J. Sea Res. 49, 95-106. doi: 10.1016/S1385-1101(02)00219-8

Smetacek, V. (1998). Biological oceanography - diatoms and the silicate factor. Nature 391, 224-225.

Søndergaard, M., and Middelboe, M. (1995). A cross-system analysis of labile dissolved organic carbon. Mar. Ecol. Prog. Ser. 118, 283-294. doi: $10.3354 /$ meps 118283

Spilling, K. (2007a). Dense sub-ice bloom of dinoflagellates in the Baltic Sea, potentially limited by high $\mathrm{pH}$. J. Plankton Res. 29, 895-901. doi: 10.1093/plankt/fbm067

Spilling, K. (2007b). On the Ecology of Cold-Water Phytoplankton in the Baltic Sea. $\mathrm{Ph} . \mathrm{D}$, University of Helsinki.

Spilling, K. (2015). Cruise Report for RV Aranda, CFLUX15 Cruise 4-15 May 2015. Available online at: http://www.syke.fi/download/noname/\%7BFB64C22533DC-46E6-800A-FB04606AB5B6\%7D/113092
Spilling, K. (2016). Cruise report for RV Aranda, CFLUX16 Cruise 4-15 April 2016. Available online at: http://www.syke.fi/download/noname/\%7B86C061C01C16-4F0F-BCFA-7778513729E9\%7D/121054

Spilling, K., Kremp, A., Klais, R., Olli, K., and Tamminen, T. (2014). Spring bloom community change modifies carbon pathways and C: N: P: Chl a stoichiometry of coastal material fluxes. Biogeosciences 11, 7275-7289. doi: 10.5194/bg-11-7275-2014

Spilling, K., Kremp, A., and Tamelander, T. (2006). Vertical distribution and cyst production of Peridiniella catenata (Dinophyceae) during a spring bloom in the Baltic Sea. J. Plankton Res. 28, 659-665. doi: 10.1093/plankt/fbi149

Spilling, K., and Lindström, M. (2008). Phytoplankton life cycle transformation lead to species-specific effects on sediment processes in the Baltic Sea. Cont. Shelf Res. 28, 2488-2495. doi: 10.1016/j.csr.2008.07.004

Spilling, K., and Markager, S. (2008). Ecophysiological growth characteristics and modeling of the onset of the spring bloom in the Baltic Sea. J. Mar. Syst. 73, 323-337. doi: 10.1016/j.jmarsys.2006.10.012

Spilling, K., Tamminen, T., Andersen, T., and Kremp, A. (2010). Nutrient kinetics modeled from time series of substrate depletion and growth: dissolved silicate uptake of Baltic Sea spring diatoms. Mar. Biol. 157, 427-436. doi: 10.1007/s00227-009-1329-4

Stepanauskas, R., Jørgensen, N. O., Eigaard, O. R., Žvikas, A., Tranvik, L. J., and Leonardson, L. (2002). Summer inputs of riverine nutrients to the Baltic Sea: bioavailability and eutrophication relevance. Ecol. Monogr. 72, 579-597. doi: 10. 1890/0012-9615(2002)072[0579:SIORNT]2.0.CO;2

Stigebrandt, A., Rahm, L., Viktorsson, L., Ödalen, M., Hall, P. O., and Liljebladh, B. (2014). A new phosphorus paradigm for the Baltic proper. Ambio 43, 634-643. doi: $10.1007 / \mathrm{s} 13280-013-0441-3$

Stipa, T. (2004). The vernal bloom in heterogeneous convection: a numerical study of Baltic restratification. J. Mar. Syst. 44, 19-30. doi: 10.1016/j.jmarsys.2003.08.006

Stolpovsky, K., Dale, A. W., and Wallmann, K. (2015). Toward a parameterization of global-scale organic carbon mineralization kinetics in surface marine sediments. Glob. Biogeochem. Cycles 29, 812-829. doi: 10.1002/2015GB005087

Stolpovsky, K., Dale, A. W., and Wallmann, K. (2018). A new look at the multi-G model for organic carbon degradation in surface marine sediments for coupled benthic-pelagic simulations of the global ocean. Biogeosciences 15, 3391-3407. doi: 10.5194/bg-15-3391-2018

Sundström, A. M., Kremp, A., Daugbjerg, N., Moestrup, Ø., Ellegaard, M., Hansen, R., et al. (2009). Gymnodinium corollarium sp. nov. (Dinophyceae) - a new cold-water dinoflagellate responsible for cyst sedimentation events in the Baltic Sea. J. Phycol. 45, 938-952. doi: 10.1111/j.1529-8817.2009.00712.x

Svedén, J. B., Adam, B., Walve, J., Nahar, N., Musat, N., Lavik, G., et al. (2015). High cell-specific rates of nitrogen and carbon fixation by the cyanobacterium Aphanizomenon sp. at low temperatures in the Baltic Sea. FEMS Microbiol. Ecol. 91:fiv131. doi: 10.1093/femsec/fiv131

Tallberg, P., and Heiskanen, A.-S. (1998). Species-specific phytoplankton sedimentation in relation to primary production along an inshoreoffshore gradient in the Baltic Sea. J. Plankton Res. 20, 2053-2070. doi: $10.1093 /$ plankt/20.11.2053

Tallberg, P., Heiskanen, A.-S., Niemistö, J., Hall, P. O., and Lehtoranta, J. (2017). Are benthic fluxes important for the availability of Si in the Gulf of Finland? J. Mar. Syst. 171, 89-100. doi: 10.1016/j.jmarsys.2017.01.010

Tamelander, T., and Heiskanen, A. S. (2004). Effects of spring bloom phytoplankton dynamics and hydrography on the composition of settling material in the coastal northern Baltic Sea. J. Mar. Syst. 52, 217-234. doi: 10.1016/j.jmarsys.2004.02.001

Tamelander, T., Spilling, K., and Winder, M. (2017). Organic matter export to the seafloor in the Baltic Sea: drivers of change and future projections. Ambio 46, 842-851. doi: 10.1007/s13280-017-0930-x

Tamminen, T. (1989). Dissolved organic phosphorus regeneration by bacterioplankton: 5'-nucleotidase activity and subsequent phosphate uptake in a mesocosm enrichment experiment. Mar. Ecol. Prog. Ser. 58, 89-100. doi: $10.3354 /$ meps058089

Tamminen, T. (1995). Nitrate and ammonium depletion rates and preferences during a Baltic spring bloom. Mar. Ecol. Prog. Ser. 120, 123-133. doi: 10.3354/meps120123

Tamminen, T., and Andersen, T. (2007). Seasonal phytoplankton nutrient limitation patterns as revealed by bioassays over Baltic Sea gradients 
of salinity and eutrophication. Mar. Ecol. Prog. Ser. 340, 121-138. doi: 10.3354/meps340121

Tedesco, L., Miettunen, E., An, B. W., Haapala, J., and Kaartokallio, H. (2017). Long-term mesoscale variability of modelled sea-ice primary production in the northern Baltic Sea. Elem. Sci. Anth. 5:29. doi: 10.1525/elementa.223

Thomas, D. N., Kaartokallio, H., Tedesco, L., Majaneva, M., Piiparinen, J., EronenRasimus, E., et al. (2017). "Life associated with Baltic Sea ice," in Biological Oceanography of the Baltic Sea (Dordrecht: Springer), 333-357.

Thornton, D. C. (2014). Dissolved organic matter (DOM) release by phytoplankton in the contemporary and future ocean. Eur. J. Phycol. 49, 20-46. doi: 10.1080/09670262.2013.875596

Vähätalo, A. V., Aarnos, H., Hoikkala, L., and Lignell, R. (2011). Photochemical transformation of terrestrial dissolved organic matter supports hetero-and autotrophic production in coastal waters. Mar. Ecol. Prog. Ser. 423, 1-14. doi: 10.3354/meps09010

Vahtera, E., Conley, D., Gustafsson, B., Kuosa, H., Pitkänen, H., Savchuk, O., et al. (2007a). Internal ecosystem feedbacks enhance nitrogen-fixing cyanobacteria blooms and complicate management in the Baltic Sea. Ambio 36, 186-194. doi: 10.1579/0044-7447(2007)36[186:IEFENC]2.0.CO;2

Vahtera, E., Laamanen, M., and Rintala, J. (2007b). Use of different phosphorus sources by the bloom-forming cyanobacteria Aphanizomenon flosaquae and Nodularia spumigena. Aquat. Microb. Ecol. 46, 225-237. doi: 10.3354/ame046225

Vehmaa, A., Kremp, A., Tamminen, T., Hogfors, H., Spilling, K., and EngströmÖst, J. (2011). Copepod reproductive success in spring-bloom communities with modified diatom and dinoflagellate dominance. ICES J. Mar. Sci. 69, 351-357. doi: 10.1093/icesjms/fsr138

Walve, J., and Larsson, U. (2007). Blooms of Baltic Sea Aphanizomenon sp.(Cyanobacteria) collapse after internal phosphorus depletion. Aquat. Microb. Ecol. 49, 57-69. doi: 10.3354/ame01130

Warns, A., Hense, I., and Kremp, A. (2012). Modelling the life cycle of dinoflagellates: a case study with Biecheleria baltica. J. Plankton Res. 35, 379-392. doi: 10.1093/plankt/fbs095

Warns, A., Hense, I., and Kremp, A. (2013). Encystment of a coldwater dinoflagellate-from in vitro to in silico. J. Mar. Syst. 125, 54-60. doi: 10.1016/j.jmarsys.2012.10.003

Wasmund, N., Kownacka, J., Göbel, J., Jaanus, A., Johansen, M., Jurgensone, I., et al. (2017). The diatom/dinoflagellate index as an indicator of ecosystem changes in the Baltic Sea. 1. Principle and handling instruction. Front. Mar. Sci. 4:22. doi: 10.3389/fmars.2017.00022
Wasmund, N., Nausch, G., and Feistel, R. (2013). Silicate consumption: an indicator for long-term trends in spring diatom development in the Baltic Sea. J. Plankton Res. 35, 393-406. doi: 10.1093/plankt/fbs101

Wasmund, N., Nausch, G., and Matthaus, W. (1998). Phytoplankton spring blooms in the southern Baltic Sea - spatio-temporal development and long-term trends. J. Plankton Res. 20, 1099-1117. doi: 10.1093/plankt/20. 6.1099

Wasmund, N., Nausch, G., Schneider, B., Nagel, K., and Voss, M. (2005). Comparison of nitrogen fixation rates determined with different methods: a study in the Baltic Proper. Mar. Ecol. Prog. Ser. 297, 23-31. doi: 10.3354/meps297023

Wasmund, N., Nausch, G., and Voss, M. (2012). Upwelling events may cause cyanobacteria blooms in the Baltic Sea. J. Mar. Syst. 90, 67-76. doi: 10.1016/j.jmarsys.2011.09.001

Wasmund, N., and Uhlig, S. (2003). Phytoplankton trends in the Baltic Sea. ICES J. Mar. Sci. 60, 177-186. doi: 10.1016/S1054-3139(02)00280-1

Wikner, J., and Andersson, A. (2012). Increased freshwater discharge shifts the trophic balance in the coastal zone of the northern Baltic Sea. Glob. Change Biol. 18, 2509-2519. doi: 10.1111/j.1365-2486.2012.02718.x

Witak, M., Dunder, J., and Leśniewska, M. (2011). Chaetoceros resting spores as indicators of Holocene paleoenvironmental changes in the Gulf of Gdansk, southern Baltic Sea. Oceanol. Hydrobiol. Stud. 40, 21-29. doi: 10.2478/s13545-011-0037-0

Wulff, F. V., Rahm, L., and Larsson, P. (2001). A Systems Analysis of the Baltic Sea. Berlin: Springer Verlag. doi: 10.1007/978-3-662-04453-7

Zlotnik, I., and Dubinsky, Z. (1989). The effect of light and temperature on DOC excretion by phytoplankton. Limnol. Oceanogr. 34, 831-839. doi: 10.4319/lo.1989.34.5.0831

Conflict of Interest Statement: The authors declare that the research was conducted in the absence of any commercial or financial relationships that could be construed as a potential conflict of interest.

Copyright (c) 2018 Spilling, Olli, Lehtoranta, Kremp, Tedesco, Tamelander, Klais, Peltonen and Tamminen. This is an open-access article distributed under the terms of the Creative Commons Attribution License (CC BY). The use, distribution or reproduction in other forums is permitted, provided the original author $(s)$ and the copyright owner(s) are credited and that the original publication in this journal is cited, in accordance with accepted academic practice. No use, distribution or reproduction is permitted which does not comply with these terms. 